\title{
Relating landscape ecological metrics with public survey data on perceived landscape quality and place attachment
}

\author{
Flurina M. Wartmann $(\mathbb{D} \cdot$ C. B. Stride $\mathbb{1} \cdot$ F. Kienast $\mathbb{C} \cdot$ M. Hunziker $\mathbb{1}$
}

Received: 20 July 2020 / Accepted: 25 June 2021 / Published online: 6 July 2021

(C) The Author(s) 2021

\begin{abstract}
Context It is essential for policy-making and planning that we understand landscapes not only in terms of landscape ecological patterns, but also in terms of their contribution to people's quality of life.

Objectives In this study our objective is to test relationships between landscape ecology and social science indicators, by investigating how landscape patterns are linked to people's perception of landscape quality.

Methods To assess public views on landscapes we conducted a survey among 858 respondents in Switzerland. We combined this survey data on perceived landscape quality and place attachment with landscape metrics (e.g. diversity, naturalness of
\end{abstract}

Supplementary Information The online version of this article (doi:https://doi.org/10.1007/s10980-021-01290-y) contains supplementary material, which is available to authorized users.

F. M. Wartmann ( $₫)$

School of Geosciences, University of Aberdeen, St Mary's, Elphinstone Road, Aberdeen AB24 3UF, UK e-mail: flurina.wartmann@abdn.ac.uk

F. M. Wartmann · F. Kienast - M. Hunziker

Swiss Federal Institute for Forest, Snow and Landscape

Research (WSL), Zürcherstrasse 111, 8903 Birmensdorf,

Switzerland

C. B. Stride

IWP, Management School, University of Sheffield,

Sheffield S10 1FL, UK land cover, urban sprawl, fragmentation) in a statistical model to test hypotheses about the relationships between the different variables of interest.

Results Our results illustrate the contribution of both landscape composition metrics and social science indicators to understanding variation in people's perception and assessment of landscape. For example, we found the landscape ecology metrics on urban sprawl and fragmentation to be a negative predictor of overall satisfaction with landscape, and that perceived landscape quality positively predicted place attachment and satisfaction with the municipality landscape. Conclusions This study highlights the importance and feasibility of combining landscape ecology metrics and public survey data on how people perceive, value and relate to landscape in an integrated manner. Our approach has the potential for implementation across a variety of settings and can contribute to holistic and integrated landscape assessments that combine ecological and socio-cultural aspects.

Keywords Landscape ecology - Landscape assessment - Visual landscape quality · Place attachment $\cdot$ Multilevel modelling 


\section{Introduction}

Understanding how people perceive and value different landscapes is essential for informing landscape policies that reflect societal needs (Butler 2016). The importance of assessing contributions of nature and landscapes to people's quality of life is increasingly recognised through frameworks such as ecosystem services and nature's contributions to people (Bieling 2014; Gould et al. 2015; Scholte et al. 2015; Díaz et al. 2018). However, whilst ecological metrics are welladvanced, assessment of how the public perceives and values landscapes is comparatively underdeveloped (Gobster et al. 2007; Fry et al. 2009; Cassatella and Peano 2011; Chan et al. 2012; Milcu et al. 2013; Wartmann and Purves 2018), particularly the relationship between a landscape's ecological and structural characteristics and public perception and values. Understanding how landscape changes-such as urbanisation or agricultural abandonment-affect people's perception and attachment to landscapes is important to inform landscape planning and policymaking (Frick and Buchecker 2008; Hunziker et al. 2008; Tobias and Müller Wahl 2013).

We take this as a starting point for this study, in which we investigate the relationship between a landscape's ecological features and the public's opinion of landscape. We examine whether physical landscape elements and structures relate to how people assess landscapes, and whether demographic background influences an individual's assessment of the landscape they live in. To address these research questions, we developed and tested a model linking landscape-ecological metrics, respondents' socio-demographic profiles, and social-science indicators including perceived landscape quality, and place attachment. The novelty of this study lies in the simultaneous investigation of such individual and landscape-level relationships, specifically via acknowledging the hierarchical data structure of people nested within landscapes and utilising advanced quantitative methodology in the form of multilevel modelling.

We first unpack - and briefly introduce approaches for assessing - the concepts of landscape ecology and methods for assessing landscape perception and interpretation.
Context

The European Landscape Convention (ELC) defines landscape as 'an area, as perceived by people, whose character is the result of the action and interaction of natural and/or human factors' (Council of Europe 2000). Signatory member countries of the ELC pledge to record the state and changes of the landscapes in their territory and to set quality objectives for landscape development. For example, the Swiss Landscape Monitoring programme (LABES) was conceptualised according to the requirement for integrated monitoring of landscapes set out in the ELC. In LABES, quantitative social and physical indicators aim to provide a holistic assessment of the state of Switzerland's landscapes and their development over time. The indicators cover both physical aspects of the landscape (e.g., urban sprawl, fragmentation) and social aspects (e.g., perceived visual landscape quality).

Landscape ecology dimensions and metrics

The physical landscape itself, consisting of different features and their composition, is the basis from which any perception and interpretation of landscape arises (Kühne 2017). Landscape ecology measures assess this aspect using a variety of dimensions and associated metrics. Landscape pattern, for example, is defined as the spatial heterogeneity found where environmental factors are unevenly distributed (Turner 2005). Objective metrics for landscape pattern are well developed, and commonly based on composition or configuration (Gustafson 1998). Landscape composition-the type and amount of land cover present-is measured by the Shannon-Weaver diversity index (Ortiz-Burgos 2016), or the proportion of an area occupied by certain habitats (Turner and Gardner 2001). Landscape configuration metrics measure how land cover is distributed in space, and include indicators of diversity, connectivity and fragmentation-for example, to what extent do human elements (streets, railways) break up ecosystems into smaller patches (Jaeger et al. 2008; Llausàs and Nogué 2012). Other landscape ecology dimensions include determining the degree of human influence or naturalness (Walz and Stein 2014). Using established metrics to measure landscape ecological dimensions enable the 
testing of relationships between these dimensions and respondents' landscape perception and interpretation.

Landscape perception and interpretation

Daniel (2001, p. 268) states that 'landscape quality arises from the relationship between properties of the landscape and the effects of those properties on human viewers'. Active debate in the study of landscape quality revolves around the nature and the assessment of this relationship. Both objectivist and subjectivist approaches have been identified (Lothian 1999).

Objectivist approaches assume that landscape quality is an objective property of landscapes that can be assessed by experts, whereas the subjectivist framework advocates that landscape quality is subjective and arises from the interactions of observers with the landscape and essentially lies in the 'eyes of the beholder' (Lothian 1999). In practice, this debate has been resolved to some extent by acknowledging that landscape quality is a function of both landscape features themselves and their perception by the observers (Daniel 2001), a conclusion that is important for landscape policy-making and planning, as well as for place branding (Tobias and Müller Wahl 2013; de San Eugenio Vela, 2017).This so-called "perceived landscape quality" can, in turn, be conceptualized in terms of both (i) the direct visual perception of landscape, as well as (ii) the interpretation of landscape (Hunziker et al. 2007; Kühne 2017).

\section{Perception of landscape}

Concepts that relate directly to perception are openness of views and complexity (Hunziker and Kienast 1999; Fry et al. 2009; Ode et al. 2010). According to Appleton (1975), humans generally prefer wide, open views. Complexity is defined as the visual diversity and richness of landscape elements: in information processing theory complexity is seen as a positive predictor of landscape preference, in combination with the three concepts of coherence, mystery and legibility (Kaplan and Kaplan 1989). Landscape complexity has both been measured as a perception indicator by asking respondents to rate visual stimuli or verbal statements about landscapes, as well as through landscape metrics (Hunziker and Kienast 1999; Ode et al. 2008, 2010; Kienast et al. 2015).

\section{Interpretation of landscape}

Similarly, when conceptualising how landscape is interpreted, we can distinguish two principal dimensions: a personal/individual interpretation of landscape and a social/cultural interpretation (Tveit et al. 2006). The scientific literature is primarily focused on the personal dimension of interpretation. We will initially introduce different social-science indicators for assessing concepts at the personal/individual level.

\section{Personal-individual interpretation of} landscape Bourassa (1988) considered assessing how beautiful a landscape is seen in the eyes of a beholder an important aspect of landscape aesthetics. Ratings of perceived landscape beauty have been used as a proxy indicator for overall visual landscape quality (Wartmann et al. 2021a), but multiple distinct elements of interpreted landscape have also been identified within the environmental psychology literature. The concept of fascination is central to Attention Restoration Theory (Kaplan 1995), encapsulating the idea that landscapes can restore our attentional capacity by effortlessly capturing our attention (Kaplan 1995) and thus aid recovery from mental fatigue (Hartig et al. 1991; Ulrich et al. 1991). Twigger-Ross and Uzzell (1996) promote distinctiveness-how special a landscape is compared to other landscapes - as one of several components of place identity. Distinctiveness was later linked to the concept of imageability laid out by Tveit et al. (2006), defined as qualities or elements that make landscapes distinguishable and memorable. In a policy-context, the perceived distinctiveness of landscapes can contribute to decision-making on how to further develop landscapes while maintaining their particularities. The concept of authenticity refers to the perceived appropriateness of elements of the landscape in relation to the place or region (Kianicka et al. 2006; Kienast et al. 2015). While authenticity is most often related to works of art or built heritage in urban environments (Jivén and Larkham 2003), it is also applicable to assess landscapes.

Regarding the influence of socio-economic backgroundon landscape perception and interpretation, in earlier work the 'consensus assumption' was prevalent, i.e. that individual differences are small and similarities between people outweigh differences between social, cultural or linguistic groups (Hartig 
and Evans 1993). However, this assumption was later challenged by highlighting that much of the 'consensus' found was due to sampling of groups with high potential for consensus: typically white, male, university-educated respondents (Van den Berg et al. 1998). Several studies reported differences related between groups of people that differ with regards to socioeconomic, socio-cultural or socio-demographic variables (Strumse 1996; Van den Berg et al. 1998; Gomez-Limon and de Lucio Fernández 1999; Gobster 2002; Dramstad et al. 2006; Natori and Chenoweth 2008; Buijs et al. 2009), highlighting the importance of taking into account socio-demographic control variables.

Furthermore, there has been extensive examination of the bonds and relations that people form with landscapes and places. One concept that has received much attention is place attachment, defined as the strength of attachment to meaningful places (Tuan 1974; Lewicka 2011). Such meaningfulness is often ascribed to homes or neighbourhoods (Bonaiuto et al. 1999), but can also refer to wider areas such as municipalities, or much smaller, 'special places' within the landscape (Brown and Raymond 2007).

Stedman $(2002,2003)$ included the alternative concept of place satisfaction as a summary evaluative judgement to assess also how satisfied respondents are with a setting in general. Place satisfaction is seen as a different concept to place attachment, because although people may be satisfied with where they live, they don't necessarily need to be particularly attached to that place (Mesch and Manor 1998).

In terms of the factors that influence satisfaction and place attachment, the duration people lived in a place was consistently found positively associated with place attachment (Lewicka 2011). Furthermore, place attachments formed in childhood were shown to be stronger than those formed later in life (Hay 1998), suggesting the place where one grew up exerts influence on adult place attachment. People having migrated from rural to urban areas were shown to exhibit nostalgia and homesickness for the rural places they grew up in (Smith 2002).

\section{Socio-cultural interpretations of landscape In} addition to individual aspects of landscape interpretation, studies have also focused on sociocultural aspects, including meanings and feelings people associate with landscape, for example tradition or spirituality (Stephenson 2008). The cultural landscape values model by Stephenson (2008) distinguished forms, practices, and relationships. Forms refer to physical, tangible and measurable aspects including historic features, natural landforms, and human-made structures. Practices refer to human activities including recreational behaviour. Such associations with landscape have been highlighted as an important influence on how people perceive and appreciate visual landscape quality (Nassauer 1992; Jorgensen 2011).

However whilst the dimensions or concepts that make up visual landscape quality and non-visual associations with landscape have been assessed as landscape indicators, the relationship between landscape metrics, and how people perceive, interpret, and relate to landscapes has seldom been jointly investigated. In this study, we test relationships between landscape ecology dimensions and respondents' landscape perception and interpretation, as set out in our hypotheses below.

\section{Hypotheses}

Our hypothesized model revolves around the relationship between how people perceive and interpret the landscape, and landscape's ecological features. These relationships are important, in that they point towards how variation in and changes to the physical landscape affect how people perceive and interpret landscape, how satisfied they are with it and how attached they feel to it. For instance, place attachment was shown to be linked to place-protective action in the context of landscape change through renewable energy projects (Devine-Wright 2009). Understanding public perception of landscape and landscape change is also important from a monitoring perspective, such as the ELC (Council of Europe 2000), but also more generally, in terms of landscape stewardship of everyday landscapes that are facing a multitude of societal demands from different stakeholders (Plieninger et al. 2015). In the context of the Swiss landscape monitoring program, we focus on Switzerland as a case study to assess these relationships.

We formulated a set of hypotheses at the personlevel and landscape-level. We used municipality as a simple proxy for a landscape-level unit. Municipalities are the lowest administrative unit in Switzerland, and are linked to people's lifeworld and experiences. 
Given that we did not collect address data from respondents for privacy reasons, we were unable to use the direct surroundings of where respondents lived. Instead, we use the municipality as spatially clearly defined boundary that many people will be broadly familiar with.

\section{Person-level hypotheses}

Our first set of hypotheses focuses on explaining variation in landscape perception between respondents living within the same landscape unit, i.e. municipality. We were particularly interested in relationships between perceived visual landscape quality, place attachment and landscape satisfaction with the landscape in the municipality. These are dimensions that we expect to be influenced by landscape change, e.g. through continued urbanization, or building of infrastructure. Previous studies support the existence of a positive relationship between perceived visual landscape quality and both place attachment (Stedman 2003) and satisfaction with the landscape (Lewicka 2011; Kienast et al. 2012). We encapsulated the relationships between these constructs within the following hypotheses, while controlling for potential confounding influences of age, gender, landscape type of respondents' childhood and accessibility to green spaces:

$\mathrm{H}_{1 \mathrm{a}} \quad$ A respondent's perception of their municipality's visual landscape quality will positively predict their place attachment to the municipality landscape.

$\mathrm{H}_{1 \mathrm{~b}}$ A respondent's perception of their municipality's visual landscape quality will positively predict their satisfaction with their municipality landscape.

Second, we test the relationship between associations with landscape (non-visual cultural landscape values) held at the individual/personal level and perceived landscape quality, which underlies thinking in landscape architecture and design (Meyer 2008) and can be encapsulated within the following hypotheses:

$\mathrm{H}_{2}$ The extent to which respondents associate their municipality landscape with non-visual cultural landscape values will positively predict their perception of municipality landscape quality.

Together Hypotheses 1 and 2 logically lead to the further hypotheses regarding indirect relationships between non-visual cultural landscape values and both place attachment and landscape satisfaction:

$\mathrm{H}_{3 \mathrm{a}}$ The extent to which a respondent associates their municipality landscape with non-visual cultural landscape values will positively predict their attachment to the municipality, with this effect operating indirectly via their perception of visual landscape quality in the municipality.

$\mathrm{H}_{3 \mathrm{~b}}$ The extent to which a respondent associates their municipality landscape with non-visual cultural landscape values will positively predict their satisfaction with their municipality landscape, with this effect operating indirectly via their perception of municipality landscape quality.

\section{Municipality-level hypotheses}

Second, we focused on explaining variation in perceived visual landscape quality, landscape satisfaction and place attachment between municipalities. The sprawl and fragmentation associated with urbanisation are typically viewed as negative by residents, particularly in more rural environments (Ströbele and Hunziker 2017). Likewise we would expect a positive effect of the diversity of landscape composition, because landscapes that offer high visual diversity are commonly preferred (Kaplan and Kaplan 1989). We expect to find a negative effect of the extent of agricultural land cover on our three landscape perception outcomes, given that high-productivity agricultural landscapes now common across Switzerland have low aesthetics ratings (Lindemann-Matthies et al. 2010). Finally, public surveys suggest that people are more likely to have a positive perception of landscapes with greater natural land cover and low human impacts (Jackson et al. 2008). Therefore, at the municipality level we tested the following hypotheses pertaining to the effects of landscape configuration and composition discussed above.

$\mathrm{H}_{4 \mathrm{a}} \quad$ Between-municipality differences in perceived landscape quality will be explained by the municipality characteristics of sprawl (negative relationship), fragmentation (negative), diversity of landscape composition (positive), natural land cover (positive), and extent of agriculture (negative).

$\mathrm{H}_{4 b}$ Between-municipality differences in attachment to municipality will be explained by the 
municipality characteristics of sprawl (negative), fragmentation (negative), diversity of landscape composition (positive), natural land cover (positive), and extent of agriculture (negative).

$\mathrm{H}_{4 \mathrm{c}}$ Between-municipality differences in satisfaction with municipality landscape will be explained by the municipality characteristics of sprawl (negative), fragmentation (negative), diversity of landscape composition (positive), natural land cover (positive), and extent of agricultural land cover (negative).

Furthermore, based on Ströbele and Hunziker's (2017) study of differences between how residents perceive landscapes in different types of municipalities, we hypothesise that these landscape configuration and composition effects will explain the relationship between type of landscape (rural vs urban) and appreciation of and attachment to it. That is, rural landscapes will, on average, report higher levels of satisfaction, perceived visual quality and place attachment because they have less sprawl and fragmentation, and more natural land cover:

$\mathrm{H}_{5 \mathrm{a}}$ Predominant type of municipality (urban vs rural) will impact on perceived landscape quality such that those in rural areas report higher levels, with this effect operating indirectly via the characteristics of sprawl, fragmentation, and natural land cover.

$\mathrm{H}_{5 \mathrm{~b}}$ Predominant type of municipality (urban vs rural) will impact on attachment to municipality, such that those in rural areas report higher levels, with this effect operating indirectly via the characteristics of sprawl, fragmentation, and natural land cover.

$\mathrm{H}_{5 \mathrm{c}}$ Predominant type of municipality (urban vs rural) will impact on satisfaction with municipality landscape such that those in rural areas report higher levels, with this effect operating indirectly via the characteristics of sprawl, fragmentation, and natural land cover.

\section{Cross-level research hypothesis}

Rural residents have been found to exhibit higher levels of place attachment than urban residents (Anton and Lawrence 2014). Integrating the importance of childhood on adult place attachment, we would expect those who grew up in rural areas but now live in primarily urban municipalities to feel least attached to their current municipality, due to their nostalgia for the countryside (Smith 2002). This hypothesis can be formalised as:

Independent of the effects described in Hypotheses $1-3$, the type of landscape a respondent grew up in (urban vs rural) will impact upon their place attachment to their municipality, with this effect varying by municipality - and with this between-municipality variability in the effect explained by the type of municipality that they currently live in (H6).

$\mathrm{H}_{6}$ Specifically, respondents who grew up in rural areas but now live in a predominantly urban municipality will be less attached to that municipality than those still living in a predominantly rural municipality. Conversely, those who grew up in urban areas but now live in a predominantly rural municipality will be more attached to their current municipality than those still living in a predominantly urban municipality.

\section{Methods}

Sampling description

This study was part of a research project on the further development of the Swiss landscape monitoring programme, for which a survey was conducted in $\mathbf{5 8}$ municipalities across Switzerland. A stratified sample of municipalities (Fig. 1) was taken, to ensure representativeness with respect to the three language areas in Switzerland (German, French and Italian) and, within the language areas, the municipality landscape types (e.g., high density peri-urban, peripheral rural) from the Swiss municipality typology (Federal Statistical Office 2012).

Data collection and measurement validation

\section{Person-level data collection}

Person-level data was collected in May and June 2019 via an online survey: in 30 municipalities, this was supplemented by collecting further respondents via a paper survey mailed to randomly selected addresses. Statistical comparisons between paper and online surveys showed no significant differences for our outcome measures and primary predictors (Wartmann et al. 2021b), and we therefore pooled data from both 


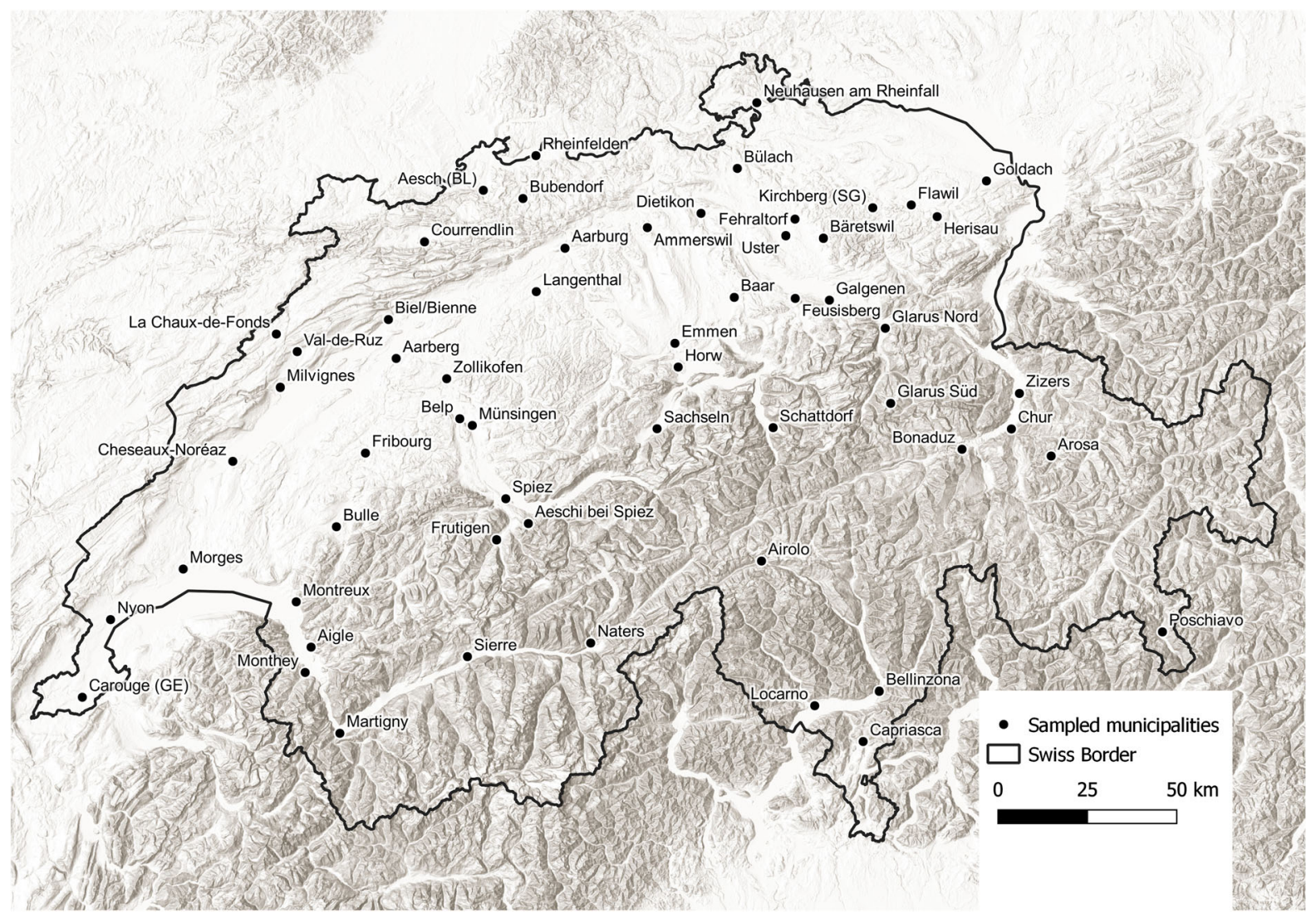

Fig. 1 Distribution of sampled municipalities across Switzerland

collection methods, giving us a final sample of 858 cases nested within 58 municipalities. Data collection was conducted by an external survey provider (DemoSCOPE AG, Adligenswil, Switzerland), a member of 'VSMS Swiss Interview Institute', who guaranteed compliance with Swiss and international quality standards and ethical norms. Survey items are given in Table 1, for full survey in original languages German, French and Italian see Wartmann et al. (2021b).

\section{Person-level outcome measures}

Place attachment to municipality (Municipality Place Attachment, Table 1) was measured by six items taken from Kienast et al.'s (2015) nine-item place attachment scale of the Swiss landscape monitoring programme, which itself is based on neighbourhood attachment studies of Bonaiuto et al. (2003) and Bonaiuto et al. (1999). Each item had a 5-point response scale labelled from 1 'Not at all' to 5
'Absolutely'. Resident satisfaction with municipality landscape was measured by three items developed for this study (Municipality Landscape Satisfaction, Table 1). Responses were collected on an 11-point scale, scored from 0 'Very Bad' to 10 'Excellent' for the items on assessment of general state of the landscape and suitability for recreation, and from 0 'Not at all content' to 10 'Very content' for items concerning satisfaction with state of the landscape.

\section{Person-level primary predictors and mediators}

Respondents' perceptions of meanings and feelings they associated with the landscapes where they lived, i.e. their non-visual cultural landscape values (Associations with Landscape, Table 1) were assessed using 24 dichotomous items, coded 1 'Yes', 0 'No'. Each item asked 'Do you associate this municipality's landscape with...' followed by a specific term denoting a feeling, emotion, or an activity shown to be 
Table 1 Survey items translated into English

Survey item

Excluded from scale

based upon EFA results

\section{Controls}

Gender

Age (years) in 2019

Grew up in large city?

Grew up in periurban area?

Grew up in mid-sized or small city or town?

Grew up in a village?

Grew up in rural area (outside village)?

Openness of views from place where you live?

Any public parks and green spaces accessible within $10 \mathrm{~min}$ on foot from where you live

Any forest accessible within $10 \mathrm{~min}$ on foot from where you live

Any meadows and agricultural areas accessible on foot within $10 \mathrm{~min}$ from where you live

Any lakes, ponds, rivers or stream accessible on foot within $10 \mathrm{~min}$ from where you live

Any mountains or hills accessible within $10 \mathrm{~min}$ on foot from where you live

Any hiking or strolling paths accessible within $10 \mathrm{~min}$ on foot from where you live

Any viewing spots accessible within $10 \mathrm{~min}$ on foot from where you live

\section{Municipality perceived visual landscape quality}

(Items relating to the dimension of landscape beauty)

The landscape in my municipality is very beautiful

I like the landscape in my municipality very much

(Items relating to the dimension of complexity)

The landscape in my municipality is varied

In the landscape of my municipality there are many different landscape elements

(Items relating to the dimension distinctiveness)

The landscape in my municipality is unique

The landscape in my municipality makes the municipality into something distinctive/special

(Items relating to the dimension of fascination)

The landscape in my municipality has fascinating properties

In this landscape in my municipality there is a lot that attracts my attention

In the landscape in my municipality there are many places where I would like to stay longer

(Items relating to the dimension of authenticity)

The landscape in my municipality seems authentic

The landscape in my municipality seems genuine

The landscape elements in my municipality seem to belong here

\section{Municipality place attachment}

I feel I belong here in my municipality

I have strong positive feelings for my municipality

This municipality feels as if it was made for me/is ideally suited to me

I could just as well spend my time somewhere else than my municipality

A large part of my life is organised around my municipality

If I moved away from my municipality, I would miss it

Municipality landscape satisfaction

Assessment of general state of landscape in municipality

Satisfaction with state of landscape in municipality 
Table 1 continued

Survey item

Excluded from scale based upon EFA results

How well suited for recreation and relaxation is landscape in municipality

\section{Associations with landscape}

Do you associate with this municipality's landscape... peace and quiet? $\quad \mathrm{X}$

Do you associate with this municipality's landscape...menace? $\quad X$

Do you associate with this municipality's landscape... being typical for Switzerland? X

Do you associate with this municipality's landscape... nostalgia? $\quad X$

Do you associate with this municipality's landscape... nothing special $\quad$ X

Do you associate with this municipality's landscape... recreation?

Do you associate with this municipality's landscape... memories?

Do you associate with this municipality's landscape... physical well-being?

Do you associate with this municipality's landscape... mental well-being?

Do you associate with this municipality's landscape... joy?

Do you associate with this municipality's landscape... spirituality?

Do you associate with this municipality's landscape... traditions?

Do you associate with this municipality's landscape... beauty?

Do you associate with this municipality's landscape... harmony?

Do you associate with this municipality's landscape... social contacts?

Do you associate with this municipality's landscape... feeling of home?

Do you associate with this municipality's landscape...freedom?

Do you associate with this municipality's landscape...connection to place/place attachment?

Do you associate with this municipality's landscape... historical significance?

Do you associate with this municipality's landscape... fresh air?

Do you associate with this municipality's landscape... awe?

Do you associate with this municipality's landscape... daily routine?

Do you associate with this municipality's landscape... longing, yearning?

Do you associate with this municipality's landscape... continuity?

Original survey was in German, French and Italian

frequently associated with landscape in the study area (Wartmann and Purves 2018).

To measure respondents' perceived visual landscape quality (Municipality Perceived Visual Landscape Quality, Table 1), we used a series of 12 items designed to capture five related dimensions of perceived visual landscape quality: complexity as an indicator of direct landscape perception, as well as distinctiveness, perceived beauty, fascination and authenticity as indicators of the interpreted landscape. This selection of indicators is based on the needs for policy-making, with different indicators relating to different policies, and on the limitations in the length of a survey to be administered to the general public. These survey items have been used and tested in previous surveys (Kienast et al. 2013, 2015; Wartmann et al. 2021a).

Specifically, perceived landscape beauty and complexity were each measured with two items (Bourassa 1988; Kienast et al. 2015; Kaplan and Kaplan 1989). The dimension of distinctiveness was likewise measured with two items, which were taken from a previously developed and empirically tested scale on distinctiveness (Gehring 2006). The dimension of fascination (Kaplan 1995) was assessed with three items based on scales developed to assess restorativeness of landscapes (Hartig et al. 1997; Laumann et al. 2001), which have been adapted and used as a fascination scale in previous studies (Gehring 2006; Kienast et al. 2015). Finally, authenticity was 
measured with three items taken from the authenticity scale in the Swiss Landscape Monitoring programme (Kienast et al. 2015). All items utilised a five-point response scale from 1 'Not at all' to 5 'Absolutely'.

\section{Person-level control variables}

We measured accessibility to green spaces and recreational infrastructure by asking respondents whether they lived within $10 \mathrm{~min}$ on foot from each of the following types of green spaces or features: public parks and green spaces; forest; meadows and agricultural areas; lakes, ponds, rivers or streams; mountains or hills; hiking or strolling paths; and viewing spots (Controls, Table 1). Each item was coded as either 1 'Yes' or 0 'No'. This selection of seven features was based on a study examining what Swiss residents considered most important for local recreation (Kienast et al. 2012). We created a total score representing the number of different types of green spaces or features within 10 min walk by adding the item scores. We also collected respondent's gender and age, along with the landscape they grew up in during childhood (1 'rural' vs 0 'urban', where urban represented large city, mid-sized or small city or town, or peri-urban landscape, and rural represented living in a small village or in the countryside outside of a village). Finally the survey asked about the degree to which a respondent's current residence offered unobstructed views of the surroundings, since openness of view has been shown to be an important aspect of landscape preference (Appleton 1984). This item was coded from 1 'Very constricted views' to 3 'Mostly free view of the surroundings' as per previous landscape monitoring assessments (Kienast et al. 2013).

\section{Person-level measure validation}

Given that several of our planned scale measuresplace attachment to municipality, satisfaction with municipality landscape, perceived visual landscape quality, and meanings, feelings or activities associated with landscape (i.e., non-visual cultural landscape values)—were either designed specifically for this study or adapted (rather than copied) from previously validated scales, we first built a measurement model for the items. We used exploratory factor analysis (EFA), with items removed if necessary, to achieve a clear item-factor solution (i.e. measurement model) without cross-loading items or singleton factors. We then attempted to validate this measurement model by testing its fit using confirmatory factor analysis (CFA) — or, where the construct was modelled at both person and municipality levels, multilevel confirmatory factor analysis (MCFA). The EFA and CFA/ MCFA analyses were performed on distinct randomlysplit halves of the dataset, a least-worst practical solution to avoid the model overfitting caused by building and testing using the same cases (Fokkema and Greiff 2017). Mplus software version 8 (Muthén and Muthén 2016) was used for all EFA, CFA and MCFA analyses.

Exploratory factor analysis of the scale items suggested that a six factor person-level solution was optimal. This was comprised of: single factors for place attachment to municipality and satisfaction with municipality landscape; a single second order factor for perceived visual landscape quality (in turn measured by factors for each of the dimensions); and three first-order factors for respondents' non-visual cultural values associated with their municipality landscape, respectively representing tradition [items "do you associate with this landscape...": traditions, memories, social contacts, feeling of home (German: "Heimat"), connectedness, historical significance, daily routine, continuity]; and spirituality/mental well-being (items "do you associate with this landscape...": mental well-being, joy, spirituality, beauty, harmony, freedom, awe, yearning); and physical wellbeing (items "do you associate with this landscape...": physical well-being, recreation, fresh air). Five of the associations with landscape items were dropped due to cross-loading or low loadings (see Table 1).

For the measurement model validation, we used MCFA to test the measurement model for the proposed municipality attachment, landscape satisfaction and perceived visual landscape quality factors, which each operated as outcomes at both person and municipality levels of the data. We performed a separate CFA for the non-visual cultural landscape values items, which were only defined as concepts at the person-level.

A three-factor person-level, three-factor municipality-level measurement model for place attachment, landscape satisfaction and perceived visual landscape quality - with the perceived visual landscape quality 
factor a second order construct measured by five first order factors for landscape beauty, complexity, distinctiveness, fascination and authenticity-offered a satisfactory fit to the data (Chi-sq $=1178.324$ on 362 df, CFI $=0.906$, RMSEA $=0.070$ ), using the commonly employed fit indices and cut-off criteria (see Gerbing and Anderson 1988; Hu and Bentler 1999). It also outperformed potential competing models in which higher order and/or lower order visual landscape quality factor(s) was simply a first order three factor construct; and in which the municipality place attachment, municipality landscape satisfaction and perceived visual landscape quality items were combined into a single factor. Model fit statistics and comparisons are given in Table 2.

The CFA results likewise supported the three-factor measurement model for associations with landscape (i.e. non-visual cultural landscape values) suggested by our EFA. Furthermore, this three-factor model, with separate factors for personal association centred on tradition; on spirituality/mental well-being; and on physical well-being, outperformed potential competing 1-factor model and 2-factor models (physical wellbeing and mental well-being factors merged). Model comparisons and fit statistics are given in Table 3.

Internal consistency reliability coefficients for all multi-item scales are given in Table 4. Both multilevel omega and multilevel alpha exceeded 0.7 at both person and municipality levels for scales with Likert type multipoint response codings, indicating a satisfactory level of reliability. For the dichotomous items measuring non-visual cultural landscape values, alpha and omega fell just slightly short of this benchmark for two of the dimensions, though with the physical well-being subscale comprised of only three items this was unsurprising.

\section{Municipality-level landscape metrics}

Variables intended to measure municipality-specific landscape ecology characteristics and features were extracted from existing landscape monitoring and national statistical data. These included predominant type of landscape in the municipality (coded 1 'Urban'; 2 'Peri-urban'; 3 'Rural': dummy coded with rural as the reference category) from the Federal Statistical Office's typology (2012). A metric for urban sprawl was calculated per municipality as a combination of settlement dispersion/density, and population/workplace density (Jaeger et al. 2010). The metric has been developed and widely applied in Europe (Siedentop and Fina 2012; Hennig et al. 2015). Input variables for the urban sprawl metric calculation were derived from Swiss TLM3D building footprint [swissTLM3D (C) 2014 swisstopo (DV033594)] and the federal statistics for population and workplaces (STATPOP and STATENT; Federal Office of Statistics 2012). Landscape fragmentation (effective mesh size) was averaged per municipality for roads $>4 \mathrm{~m}$ wide that are assumed to divide habitats (Jaeger et al.

Table 2 Comparing competing multilevel measurement models for perceived landscape quality, personal attachment to municipality, and personal satisfaction with municipality landscape

\begin{tabular}{|c|c|c|c|c|c|c|c|}
\hline Measurement model & Chi-sq, df & $\begin{array}{l}\Delta \text { Chi-sq, } \\
\Delta \text { df }\end{array}$ & $p$ & CFI & RMSEA & $\begin{array}{l}\text { SRMR } \\
\text { within }\end{array}$ & $\begin{array}{l}\text { SRMR } \\
\text { between }\end{array}$ \\
\hline 1 Factor within; 1 factor between & $\begin{array}{c}2943.567 \\
378\end{array}$ & - & - & 0.704 & 0.121 & 0.090 & 0.665 \\
\hline 3 Factors within; 1 factor between & $\begin{array}{c}1790.127 \\
375\end{array}$ & $\begin{array}{c}1153.44 \\
3 *\end{array}$ & $<0.001$ & 0.837 & 0.090 & 0.059 & 0.607 \\
\hline 3 Factors within; 3 factors between & $\begin{array}{c}1602.078 \\
372\end{array}$ & $\begin{array}{c}188.049 \\
3 *\end{array}$ & $<0.001$ & 0.858 & 0.084 & 0.058 & 0.577 \\
\hline $\begin{array}{l}3 \text { Factors within (perceived visual landscape quality as } \\
\text { second order factor measured by } 5 \text { first order factors); } \\
3 \text { factors between (perceived visual landscape quality } \\
\text { as second order factor measured by } 5 \text { first order } \\
\text { factors) }\end{array}$ & $\begin{array}{c}1178.324 \\
362\end{array}$ & $\begin{array}{c}423.754 \\
10^{*}\end{array}$ & $<0.001$ & 0.906 & 0.070 & 0.054 & 0.329 \\
\hline
\end{tabular}

$\mathrm{N}=456$ (random half of data not used for EFA)

$* p<0.05$ 
Table 3 Comparing competing measurement models for non-visual cultural landscape values

\begin{tabular}{|c|c|c|c|c|c|c|}
\hline Measurement model & Chi-sq, df & $\Delta$ Chi-sq, $\Delta$ df & $p$ & CFI & RMSEA & SRMR \\
\hline 1 Factor & $641.230,152$ & - & - & 0.801 & 0.084 & 0.129 \\
\hline $\begin{array}{l}2 \text { Factors (mental well-being, physical } \\
\text { well-being items load on to single factor) }\end{array}$ & $441.313,151$ & $199.917,1^{*}$ & $<0.001$ & 0.882 & 0.065 & 0.111 \\
\hline $\begin{array}{l}3 \text { Factors (separate factors for mental } \\
\text { well-being, physical well-being, tradition) }\end{array}$ & $392.589,149$ & $48.724,2^{*}$ & $<0.001$ & 0.901 & 0.060 & 0.105 \\
\hline
\end{tabular}

$\mathrm{N}=456$ (random half of data not used for EFA)

$* p<0.05$

Table 4 Multilevel reliability coefficients for the different proposed scales

\begin{tabular}{lllllll}
\hline $\begin{array}{l}\text { Multilevel reliability } \\
\text { coefficients }\end{array}$ & $\begin{array}{l}\text { Municipality } \\
\text { Perceived } \\
\text { Visual } \\
\text { Landscape } \\
\text { Quality }\end{array}$ & $\begin{array}{l}\text { Municipality } \\
\text { Place }\end{array}$ & $\begin{array}{l}\text { Municipality } \\
\text { Landscape } \\
\text { Satisfaction }\end{array}$ & $\begin{array}{l}\text { Extent } \\
\text { municipality } \\
\text { landscape } \\
\text { associated } \\
\text { with } \\
\text { 'tradition' }\end{array}$ & $\begin{array}{l}\text { Extent municipality } \\
\text { landscape } \\
\text { associated with } \\
\text { 'spirituality/mental } \\
\text { well-being' }\end{array}$ & $\begin{array}{l}\text { Extent } \\
\text { municipality } \\
\text { landscape } \\
\text { associated with } \\
\text { 'physical well- } \\
\text { being' }\end{array}$ \\
\hline $\begin{array}{l}\text { Omega within } \\
\text { Omega between }\end{array}$ & 0.948 & 0.854 & 0.911 & 0.610 & 0.753 & 0.670 \\
Alpha within & 0.880 & 0.887 & 0.968 & - & - & - \\
Alpha between & 0.944 & 0.849 & 0.909 & 0.636 & 0.761 & - \\
\hline
\end{tabular}

2008). Input data were derived from TLM3D streets [swissTLM3D (c) 2014 swisstopo (DV033594)]. Diversity of landscape composition was measured through the Shannon diversity index (Ortiz-Burgos 2016) calculated in a $1 \mathrm{~km}^{2}$ moving window with eight aggregated land use classes: industry, supply and disposal (1); settlement (2); transport infrastructure (3); grassland and arable land (4); alpine pastures (5); forest (6); waters (7); boulders, rock (8), according to 'Arealstatistik 2004/2009' (Federal Statistical Office 2011), with data provided by GEOSTAT, the geoinformation centre within the Federal Statistical Office. To measure natural land cover, we selected the AREA classes from 'Arealstatistik' (Federal Statistical Office 2011) encompassing unproductive land use, mainly high elevation land cover types (scrubs, rocks, cliffs, screes, sand, glaciers; AREA classes 65, 69, 70 and 72). To measure agricultural area we selected arable land, orchards, pastures, etc. (i.e. land cover classes 37-44), but no high-elevation grazing areas from 'Arealstatistik 2004/2009' (Federal Statistical Office 2011).

\section{Statistical analysis}

Having established scale validity at the person-level, we first computed scale mean (i.e. composite) scores for our measures of associations with landscape, perceived landscape quality, municipality place attachment and municipality landscape satisfaction. Ideally, we would have treated these measures as latent variables when modelling relationships between them, but our relatively small municipality-level sample size prohibited that approach. Then, by sequentially adding predictive paths between these scale mean scores themselves, and further observed variables, at both the person-level and municipality level, we fitted the multilevel structural equation model (MSEM) illustrated in Fig. 2.

Specifically, starting with a model in which outcome variance was simply partitioned into person and municipality components (model 1), our control variables (model 2) and the subscales associations of mental well-being, physical well-being and tradition with the municipality (model 3 ) were added as personlevel predictors of perceived visual landscape quality. 
Our hypothesised mediator, perceived visual landscape quality, in turn predicted our outcomes, municipality place attachment and municipality landscape satisfaction (model 4, testing Hypotheses 1-3).

At the municipality level, predominant landscape type (urban vs. peri-urban vs. rural) was added as a predictor of each outcome (coded into dummy variables representing urban and peri-urban, with rural as the reference category), with its effect operating directly and via proposed mediators representing the different landscape ecological metrics per municipality (models 6-8, Hypotheses 4-5). Finally, we allowed the person-level effect between landscape type respondents grew up in (rural vs. urban) and municipality place attachment to be a random effect, that is, for the regression coefficient to vary between municipality (model 9). Predominant landscape type was then added as a predictor of this municipality level random slope variability (model 10, Hypothesis 6, illustrated in Fig. 2).

Competing models were tested using the change in the model deviance, which has a chi-square distribution, and also assessed via the change in the personlevel or subject level outcome variance explained, as appropriate. Models were estimated by Maximum
Likelihood Estimation, again using Mplus version 8 software. All person-level predictors were municipality-mean-centered. Indirect effects were tested using confidence intervals derived via Monte Carlo simulation (Preacher and Selig 2010; Hayes 2017). Since municipalities were not directly adjacent, models did not include within-municipality spatial autocorrelation parameters.

\section{Results}

Means, standard deviations, and bivariate correlations between the study variables are given in Tables 5 and 6.

Competing models are described in Table 7, with coefficients from the final model (as per Fig. 2) and estimates of indirect effects at each level given in Tables 8, 9 and 10 respectively, with the statistically significant paths illustrated in Fig. 4. Having fitted the unconditional model, and then added person-level effects of control variables and the direct effects of non-visual cultural landscape values (models 1-3), adding paths from a respondent's perceived visual landscape quality to both their place attachment and

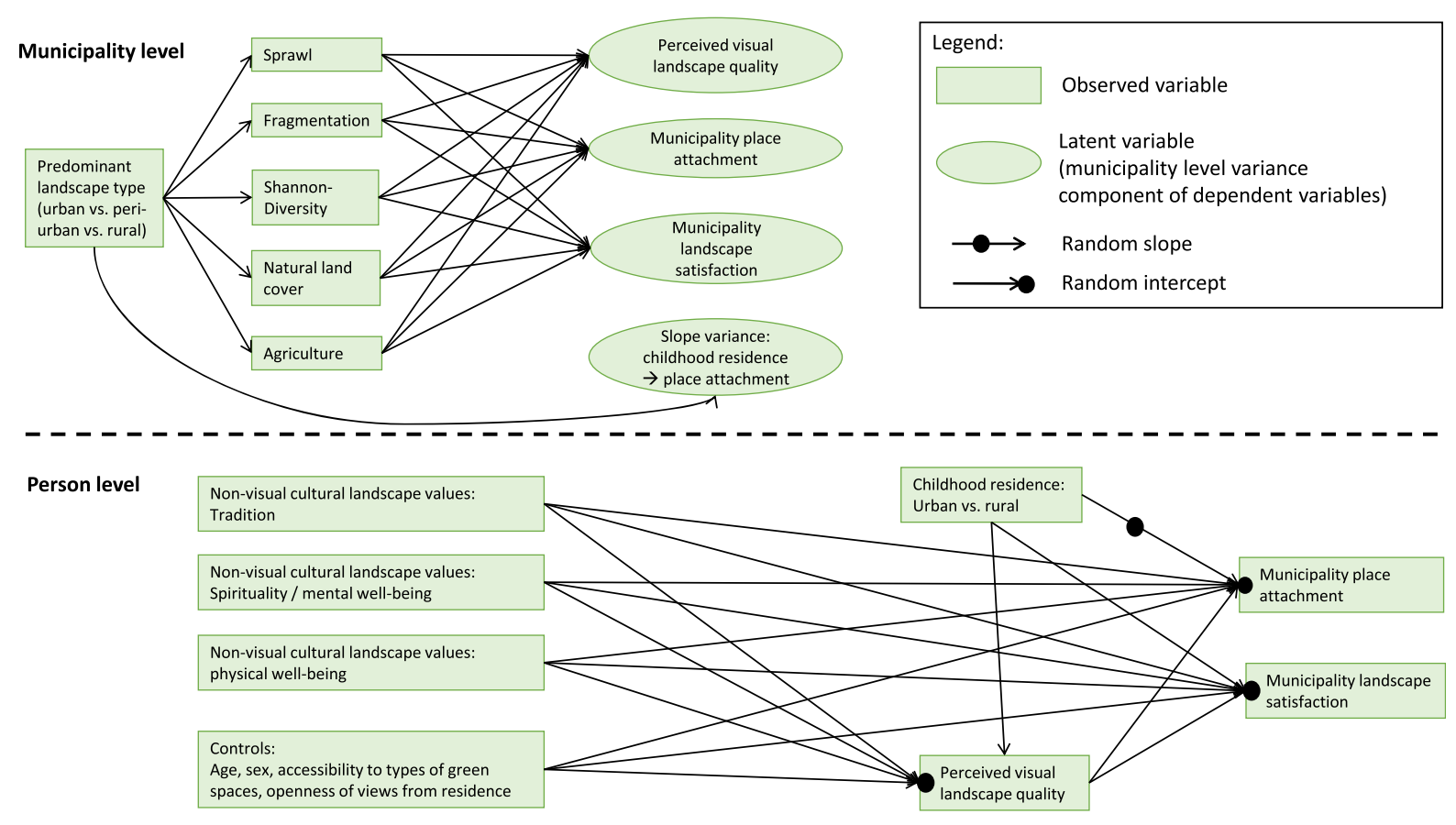

Fig. 2 Multilevel structural equation model for perceived landscape quality, place attachment and landscape satisfaction (model 10). Personal level variables are municipality-mean-centered 
their satisfaction with their municipality landscape significantly improved model fit (Table 7 model 4; $\Delta$ Deviance vs. model $3=419.234$ on $2 \mathrm{df}, \mathrm{p}<0.001$, variance explained in place attachment to municipality $=23.7 \%$, variance explained in satisfaction with their municipality landscape $=18.5 \%$ ). Effects of perceived visual landscape quality on both outcomes were statistically significant and positive, thus supporting Hypotheses $1 \mathrm{a}$ and $1 \mathrm{~b}$.

Adding paths from each dimension of non-visual cultural landscape values (the physical well-being, mental well-being and tradition associations with landscape) to perceived visual landscape quality also significantly improved model fit (Table 7 model 5; $\Delta$ Deviance vs. model $4=155.368$ on $3 \mathrm{df}$, p $<0.001$, variance explained in perceived visual landscape quality $=15.4 \%$ ), supporting Hypothesis 2. Each of the three types of non-visual cultural landscape values had a significant positive effect on perceived landscape quality. When assessing the indirect paths from non-visual cultural landscape values to each outcome via perceived visual landscape quality, the paths from tradition, from mental well-being, and from physical well-being each had a significant positive indirect effect upon municipality place attachment and

Table 5 Means, standard deviations, and bivariate correlations between the within-municipality (i.e. participant-level) study variables

\begin{tabular}{|c|c|c|c|c|c|c|c|c|c|c|c|c|c|}
\hline & Variables $^{\mathrm{a}}$ & Mean $^{\mathrm{a}}$ & $\begin{array}{l}\text { Std } \\
\text { Dev }\end{array}$ & 1 & 2 & 3 & 4 & 5 & 6 & 7 & 8 & 9 & 10 \\
\hline 1 & Age (years) & 0.00 & 14.66 & & & & & & & & & & \\
\hline 2 & $\begin{array}{l}\text { Gender }(1=\text { Male } \\
0=\text { Female })\end{array}$ & 0.00 & 0.48 & 0.24 & & & & & & & & & \\
\hline 3 & $\begin{array}{l}\text { Childhood area of residence } \\
(1=\text { Grew up in rural } \\
\text { area, } 0=\text { large city, mid- } \\
\text { sized or small city or } \\
\text { town, peri-urban) }\end{array}$ & 0.00 & 0.46 & -0.01 & 0.00 & & & & & & & & \\
\hline 4 & $\begin{array}{l}\text { Openness of views from } \\
\text { residence }\end{array}$ & 0.00 & 0.63 & -0.06 & -0.06 & 0.09 & & & & & & & \\
\hline 5 & $\begin{array}{l}\text { Number of green space } \\
\text { types accessible on foot } \\
\text { within } 10 \mathrm{~min} \text { of } \\
\text { residence }\end{array}$ & 0.00 & 1.24 & -0.05 & 0.05 & -0.03 & -0.15 & & & & & & \\
\hline 6 & $\begin{array}{l}\text { Non-visual cultural } \\
\text { landscape values: } \\
\text { spirituality/mental well- } \\
\text { being }\end{array}$ & 0.00 & 0.24 & 0.03 & -0.06 & -0.03 & -0.09 & 0.24 & & & & & \\
\hline 7 & $\begin{array}{l}\text { Non-visual cultural } \\
\text { landscape values: } \\
\text { tradition }\end{array}$ & 0.00 & 0.23 & 0.01 & -0.02 & 0.02 & 0.00 & 0.09 & 0.34 & & & & \\
\hline 8 & $\begin{array}{l}\text { Non-visual cultural } \\
\text { landscape values: physical } \\
\text { well-being }\end{array}$ & 0.00 & 0.32 & 0.09 & 0.01 & -0.09 & -0.11 & 0.29 & 0.56 & 0.12 & & & \\
\hline 9 & $\begin{array}{l}\text { Perceived visual landscape } \\
\text { quality }\end{array}$ & 0.00 & 0.69 & 0.04 & 0.02 & -0.02 & -0.20 & 0.39 & 0.44 & 0.27 & 0.39 & & \\
\hline 10 & $\begin{array}{l}\text { Municipality place } \\
\text { attachment }\end{array}$ & 0.00 & 0.84 & 0.08 & -0.01 & -0.06 & -0.15 & 0.28 & 0.35 & 0.33 & 0.34 & 0.69 & \\
\hline 11 & $\begin{array}{l}\text { Municipality landscape } \\
\text { satisfaction }\end{array}$ & 0.00 & 1.49 & 0.04 & 0.02 & -0.12 & -0.20 & 0.35 & 0.36 & 0.13 & 0.37 & 0.63 & 0.47 \\
\hline
\end{tabular}

$\mathrm{N}=766$ participants

${ }^{\mathrm{a}}$ All participant-level variables were municipality-mean-centered, hence the sample mean scores $=0$ 
Table 6 Means, standard deviations, and bivariate correlations for municipality-level variables

\begin{tabular}{|c|c|c|c|c|c|c|c|c|c|c|c|c|}
\hline & Variables & Mean & $\begin{array}{l}\text { Std } \\
\text { Dev }\end{array}$ & 1 & 2 & 3 & 4 & 5 & 6 & 7 & 8 & 9 \\
\hline 1 & $\begin{array}{l}\text { Predominant } \\
\text { municipality } \\
\text { landscape type } \\
\text { dummy variable } \\
\text { (urban vs. rural) }\end{array}$ & 0.64 & 0.48 & & & & & & & & & \\
\hline 2 & $\begin{array}{l}\text { Predominant } \\
\text { municipality } \\
\text { landscape type } \\
\text { dummy variable } \\
\text { (peri-urban vs. rural) }\end{array}$ & 0.22 & 0.42 & -0.71 & & & & & & & & \\
\hline 3 & $\begin{array}{l}\text { Municipality } \\
\text { landscape: extent of } \\
\text { natural land cover }\end{array}$ & 0.03 & 0.03 & -0.29 & -0.21 & & & & & & & \\
\hline 4 & $\begin{array}{l}\text { Municipality } \\
\text { landscape: extent of } \\
\text { agricultural land } \\
\text { cover }\end{array}$ & 0.29 & 0.16 & -0.04 & 0.31 & -0.62 & & & & & & \\
\hline 5 & $\begin{array}{l}\text { Municipality } \\
\text { landscape: extent of } \\
\text { diversity }\end{array}$ & 0.99 & 0.19 & 0.45 & -0.22 & -0.56 & 0.20 & & & & & \\
\hline 6 & $\begin{array}{l}\text { Municipality } \\
\text { landscape: extent of } \\
\text { sprawl }\end{array}$ & 15.31 & 12.47 & 0.56 & -0.30 & -0.54 & -0.01 & 0.82 & & & & \\
\hline 7 & $\begin{array}{l}\text { Municipality } \\
\text { landscape: extent of } \\
\text { fragmentation }\end{array}$ & 100.95 & 170.18 & 0.05 & -0.15 & 0.35 & -0.28 & -0.39 & -0.26 & & & \\
\hline 8 & $\begin{array}{l}\text { Perceived visual } \\
\text { landscape quality }\end{array}$ & 3.79 & 0.30 & -0.27 & -0.11 & 0.46 & -0.36 & -0.14 & -0.26 & -0.08 & & \\
\hline 9 & $\begin{array}{l}\text { Municipality place } \\
\text { attachment }\end{array}$ & 3.53 & 0.21 & -0.05 & -0.14 & 0.16 & -0.19 & 0.02 & 0.05 & -0.11 & 0.67 & \\
\hline 10 & $\begin{array}{l}\text { Satisfaction with } \\
\text { municipality } \\
\text { landscape }\end{array}$ & 7.74 & 0.50 & -0.56 & 0.34 & 0.22 & 0.05 & -0.28 & -0.50 & -0.27 & 0.75 & 0.61 \\
\hline
\end{tabular}

$\mathrm{N}=58$ municipalities

landscape satisfaction (see Table 5, indirect effects). This offers support for Hypotheses $3 \mathrm{a}$ and $3 \mathrm{~b}$.

At the municipality level of the model, adding paths from the five landscape ecological metrics to betweenmunicipality variation in perceived visual landscape quality, municipality place attachment and landscape satisfaction significantly improved model fit (Table 7 model 7; $\Delta$ Deviance vs. model $6=28.046$ on $15 \mathrm{df}$, $\mathrm{p}=0.021$, between municipality variance explained in perceived visual landscape quality $=20.9 \%$; in municipality place attachment $=2.2 \%$, in satisfaction with municipality landscape $=18.6 \%$ ). There were statistically significant negative effects of both urban sprawl and fragmentation on landscape satisfaction, supporting Hypothesis 4c, though not on place attachment or perceived visual landscape quality (hence not supporting Hypotheses $4 \mathrm{a}$ and $4 \mathrm{~b}$ ). The only statistically significant municipality level indirect effect between municipality landscape type and landscape satisfaction operated via sprawl (relative indirect effect of urban vs. rural on landscape satisfaction, via sprawl $=-0.476,95 \%$ Monte Carlo simulated $\mathrm{CI}=-0.941,-0.011$ ), offering partial support for Hypotheses 5c only.

Finally, we allowed the person-level effect of landscape type where respondents grew up on 


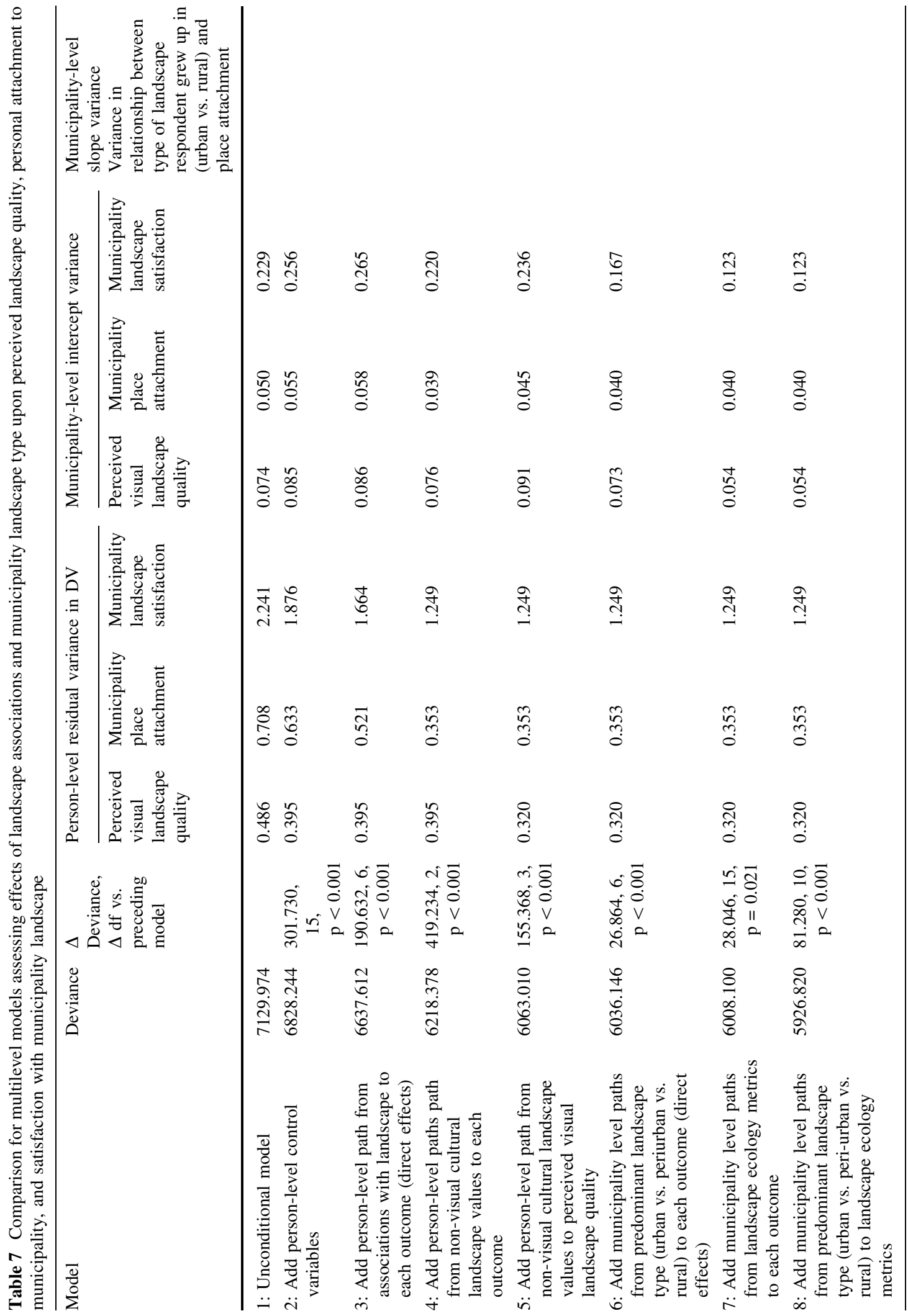




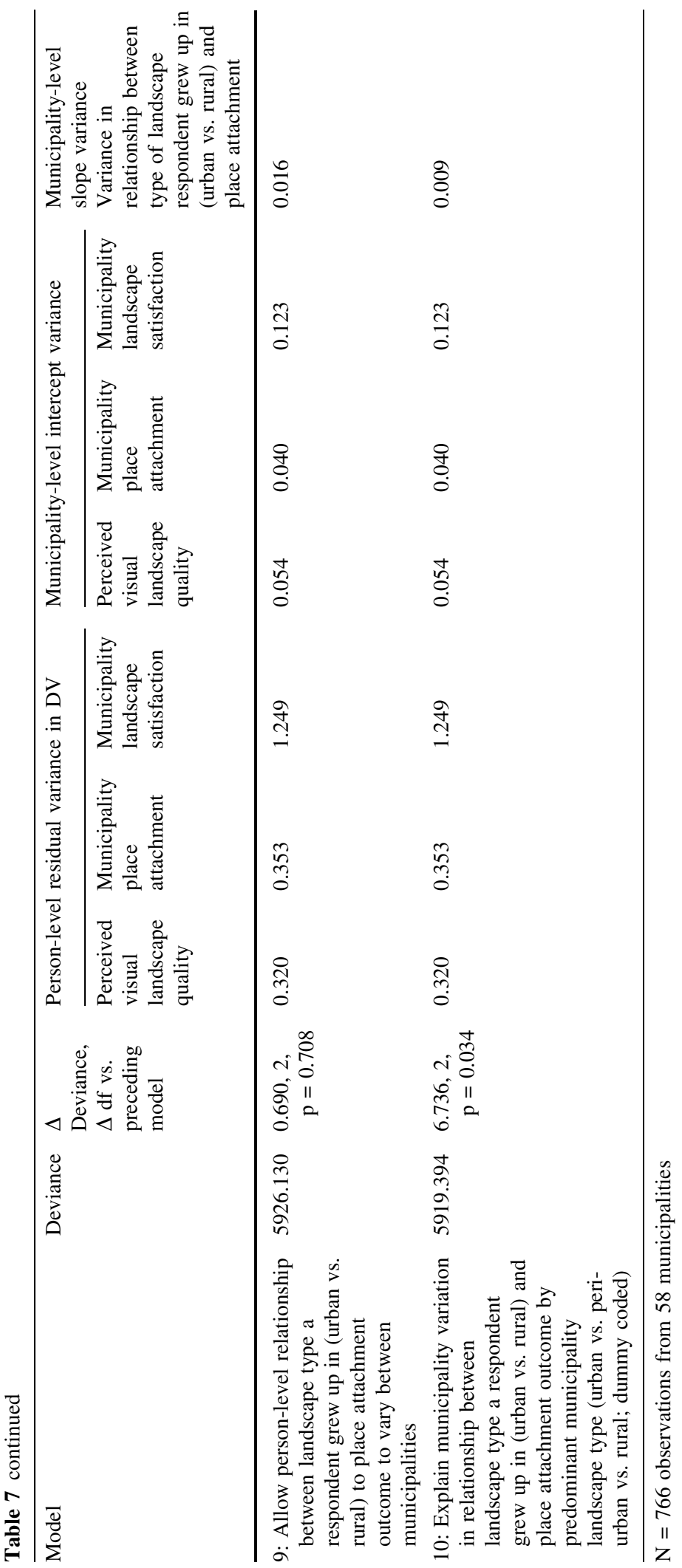




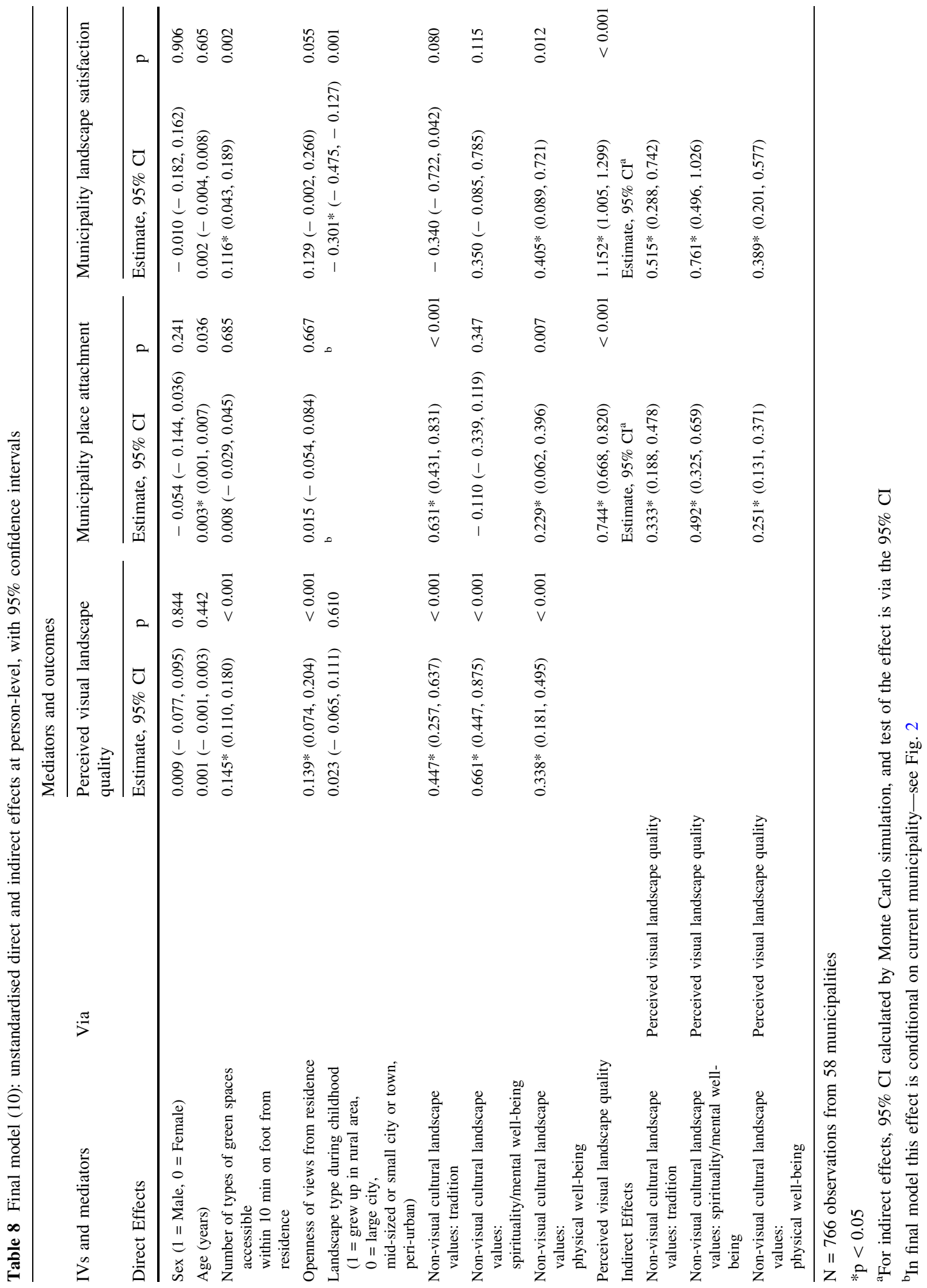




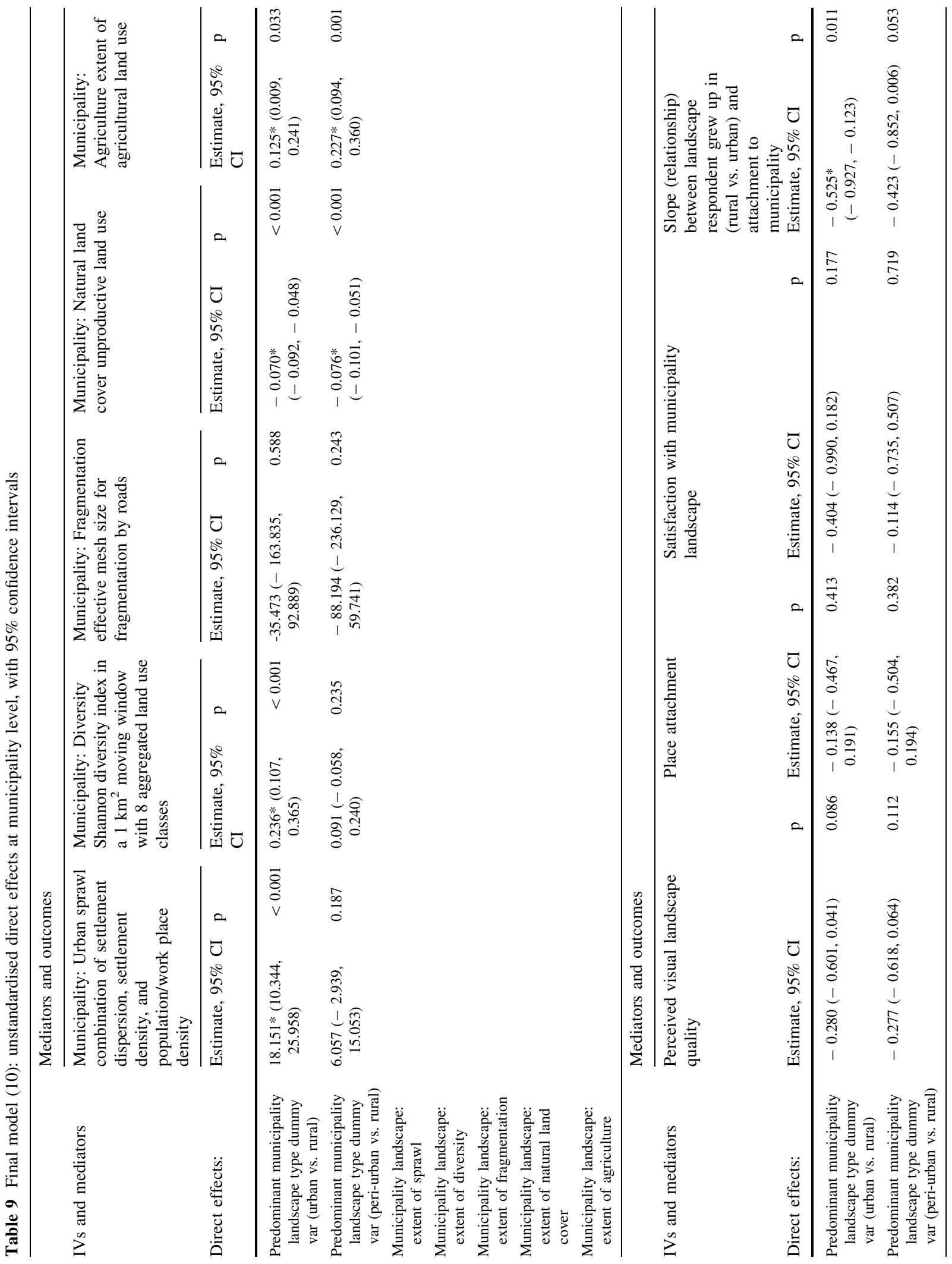




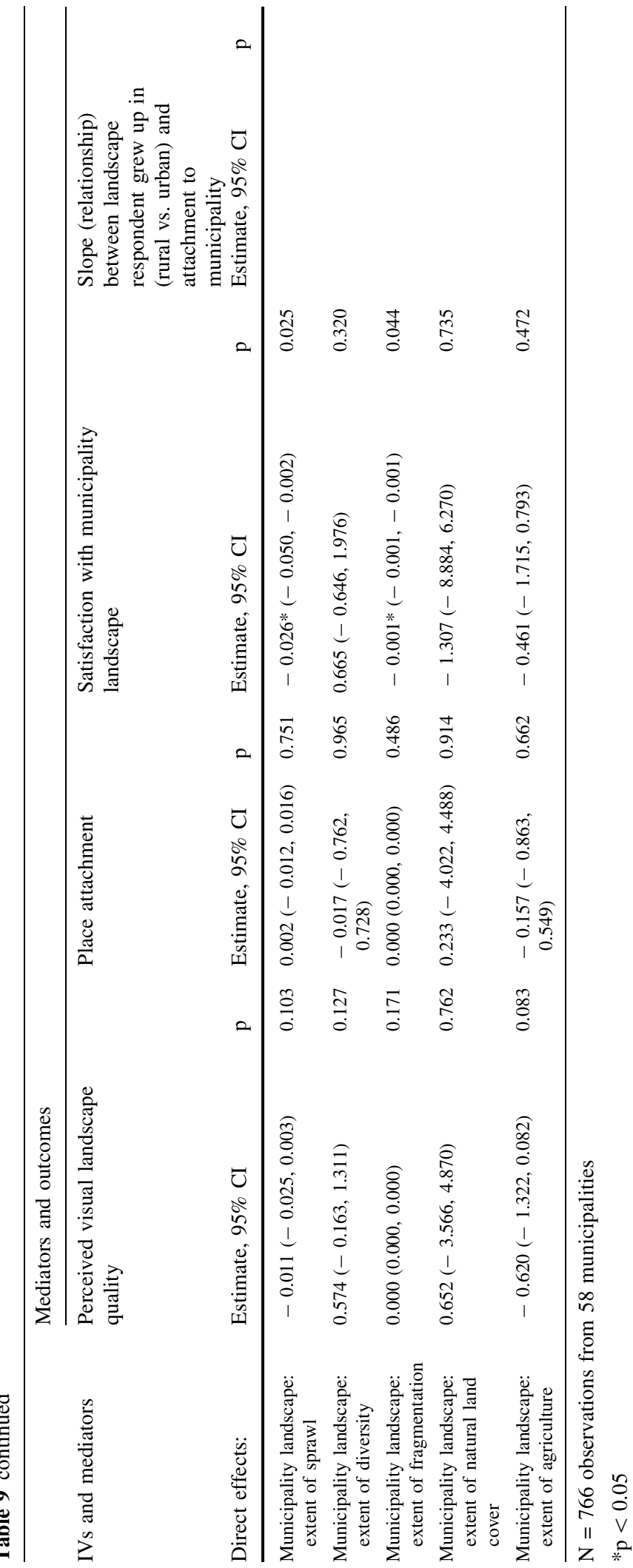


Table 10 Final model (10): unstandardised indirect effects at municipality level, with $95 \%$ confidence intervals ${ }^{\mathrm{b}}$

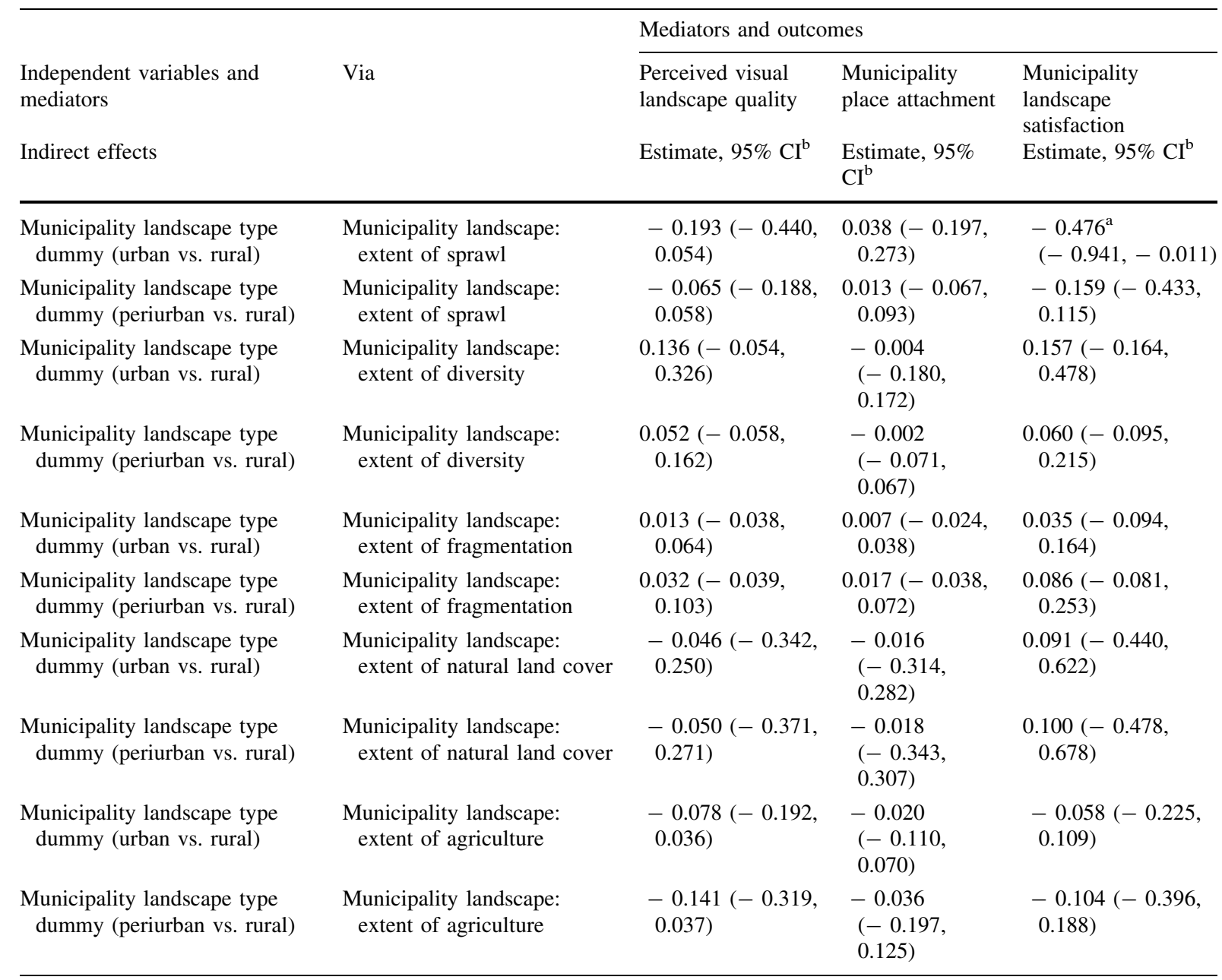

$\mathrm{N}=766$ observations from 58 municipalities

a95\% Confidence Interval doesn't contain 0

b95\% Confidence Interval calculated by Monte Carlo simulation

municipality place attachment to vary by municipality (model 9). This variation was in part explained by current municipality type (Table 7 model 10; $\Delta$ Deviance vs. model $9=6.736$ on $2 \mathrm{df}, \mathrm{p}=0.034$, variance explained in childhood landscape type on place attachment slope effect $=43.8 \%$ ), such that subjects who grew up in rural landscapes but currently living in urban landscapes reporting the lowest level of place attachment to current municipality (Fig. 3). This offers support for Hypothesis 6 . The coefficients from the final model are illustrated in Fig. 4.

\section{Discussion}

Understanding the relationships between ecological aspects of landscape and how residents relate to landscape is important for policy-making and planning — but the development and application of social science landscape assessments lags behind ecological indicators (Cassatella and Peano 2011). Furthermore, although integration of social and ecological aspects of landscapes are crucial, we identified a research gap regarding the capture of both the public's perceptions of a landscape, and the testing of relationships between these perceptions, interpretations and a 


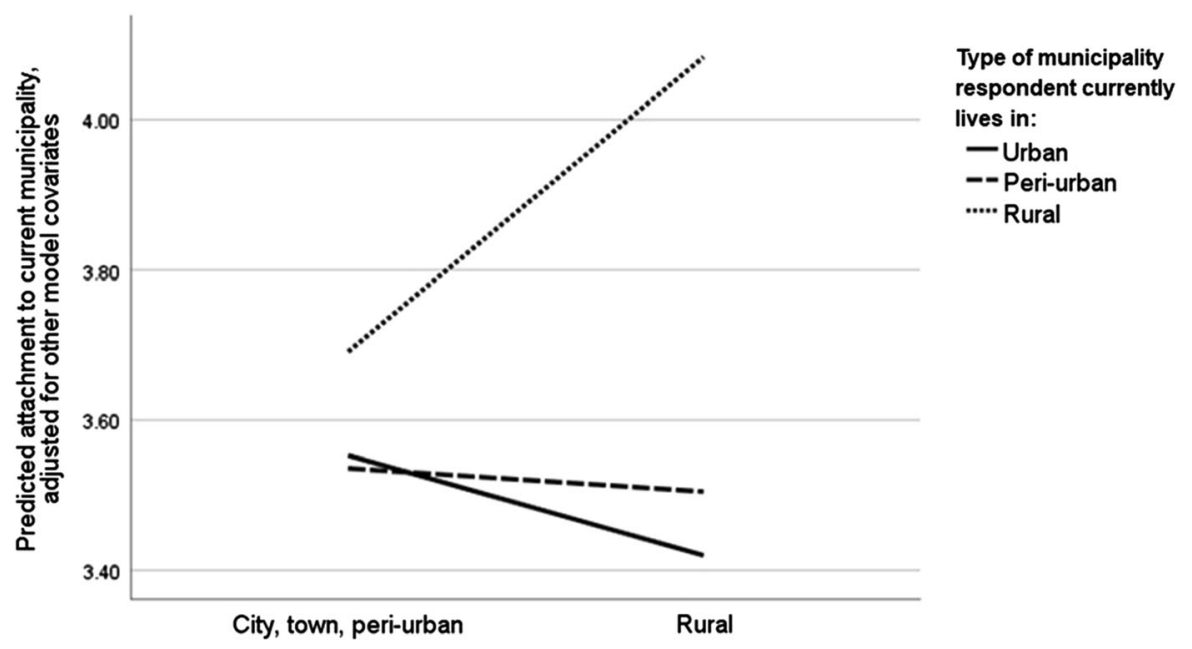

Predominant type of landscape that respondent grew up in during childhood

Fig. 3 Predicted personal attachment to current municipality by childhood municipality landscape type and current municipality landscape type

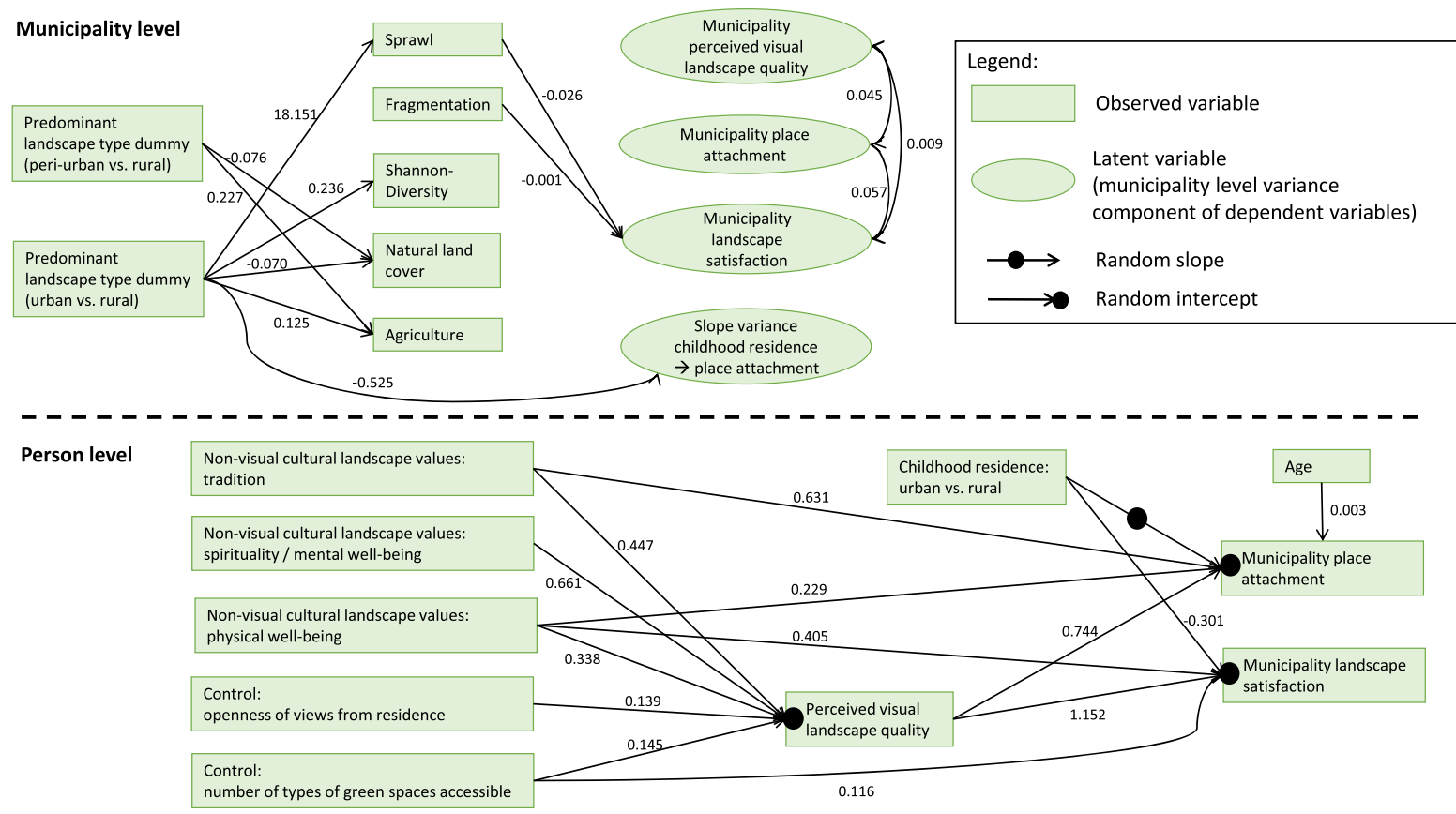

Fig. 4 Unstandardized regression coefficients for statistically significant relationships within final model (10)

landscape's ecological features. When theorising and testing models for such relationships, it is essential to distinguish between the person-level (i.e. explaining variation between individuals within the same landscape unit) and the landscape-level (explaining variation between landscapes). Testing these relationships together requires advanced quantitative modelling approaches suited to such multilevel data, of which there are few examples within landscape research literature (e.g. Hegetschweiler et al. 2017). We have attempted to address this gap, by combining ecological data and social science assessments of landscape 
through an empirical study across 58 Swiss municipalities. The novelty of our approach lies in both the integration of these data sources, and the use of multilevel modelling to simultaneously test hypotheses at person and municipality levels.

Variation between respondents within landscapes

We found considerable variation between respondents living within the same municipality. In testing our hypotheses, perceived visual landscape quality positively predicted place attachment and satisfaction with the municipality landscape, supporting Stedman's 'Meaning-Mediated Model' of place attachment (2003, p. 674). Stedman's model suggests that physical landscape features do not directly produce place attachment, but influence the symbolic meanings of the landscape, which are in turn associated with attachment. In our model, the physical landscape setting creates what people then interpret as visual landscape quality, which in turn positively affects their place attachment.

Non-visual cultural landscape values, in the form of tradition, mental well-being and physical well-being each had a significant positive effect on perceived visual landscape quality. Furthermore, operating indirectly via perceived visual landscape quality, they each positively predicted place attachment. These results indicate that both visual and non-visual aspects have an influence on quality, satisfaction and place attachment, which underlines the importance of including social aspects in landscape assessments that go beyond visual ratings (Dakin 2003).

We also found that respondents who grew up in rural landscapes but now live in urban or peri-urban landscapes exhibit lower place attachment than those who grew up and still live in rural landscapes, or respondents who grew up and still live in urban/periurban settings. This suggests familiarity with a landscape type through childhood experience acts on current place attachment-but that this effect is influenced by both the landscape type they grew up in and reside in now. This finding merits further exploration to test assumptions such as that rural landscapes are infused with more nostalgic associations than urban landscapes, and that moving from a rural to an urban setting may be associated with a sense of loss (Smith 2002).
Landscape level: variation between municipalities

At the landscape level, we found urban sprawl and fragmentation to be significantly negatively related to reported satisfaction with landscape. From a policyperspective, this supports a continued focus on limiting sprawl, which is negatively influencing satisfaction. The extent of natural land cover was positively related to landscape quality and satisfaction, whereas extent of agricultural land cover was a negative predictor, although these effects were not statistically significant. However, this lack of significance has to be interpreted given the strength of the relationships indicated by the proportion of variance explained and the lack of statistical power at the landscape level, of which the latter is a major limitation of this study. Furthermore, treating all agricultural land homogeneously does not take into account the variation in agricultural lands from monotonous to highly structured agricultural landscapes.

\section{Limitations and further work}

One of the major limitations of this study is the use of municipality as the landscape-level unit. Given that municipalities may well be comprised of different types of landscapes, the concept of predominant municipality landscape type is unlikely to reflect the landscape experienced across the entire area, in turn attenuating estimated relationships between predominant municipality landscape and ecological features. However, municipality is a spatial unit which is widely recognised among the Swiss public and allows linking public opinion to established landscape ecology metrics.

Although previous studies linking social aspects of landscape perception with landscape ecological data utilised smaller numbers of landscape units (Hegetschweiler et al. 2017), municipality-level sample size is still a major limitation in our study when testing the impacts of ecological metrics. Given common limitations on respondents sampled due to available resources, we consider sampling fewer respondents from each, but of more landscape units to increase statistical power for testing landscape-level hypotheses.

Although we detected relationships between landscape metrics and perceived landscape qualities, it is also necessary to investigate the effect of scale on 
landscape metrics applied. For instance, we used 1 $\mathrm{km}^{2}$ resolution to calculate Shannon's diversity index, because we assume this resolution relates to the mesoscale at which landscape is perceived, but this may not be appropriate across all landscapes. Although we found some relation to landscape perception, we argue that the effect of scales at which metrics are calculated on the relation with perceived landscape quality needs to be investigated in more detail.

\section{Conclusion}

In line with calls for holistic and integrated landscape assessment and monitoring, as set out, for instance, in the European Landscape Convention (Council of Europe 2000), this study highlights the importance and feasibility of combining landscape ecology and social science landscape assessments. For instance, we found statistically significant negative relations between landscape ecology metrics such as urban sprawl and fragmentation, and public assessment. By highlighting such relationships, our findings allow policy and decision-makers to anticipate how change in physical landscape properties is likely to affect public views. Investigating the multifaceted societylandscape relations and perceptions is particularly relevant as we expect physical landscape change in the future through e.g. the impacts of climate change on landscapes as well as continued landscape development through urbanisation, and agricultural abandonment in more remote areas. Furthermore, we found relationships at the personal level, i.e., within people living within the same municipality, there were positive effects of perceived visual landscape quality on place attachment and satisfaction with landscape. Through the use of advanced statistical modelling we disentangle variation between individuals and between landscapes, which is essential for understanding the effects of landscape policies and landscape change affects how people assess the quality and their relations to these landscapes.

By integrating landscape ecology and social science approaches for policy-relevant research on landscapes and the non-material benefits they provide to people, this study brings to the fore additional insights from such interdisciplinary research. We argue that there is a need for future research that is methodologically pluralistic, and also conceptually integrative and inclusive-allowing for multiple conceptualisations of landscapes and people-place relations to be integrated. Such approaches are needed for assessments to provide evidence for decision making to develop landscapes that are of high ecological quality and contribute to a high quality of life for the public.

Acknowledgements The data collection and research for this paper was financially supported through the Swiss Federal Office for the Environment (FOEN). The views and opinions expressed in this paper are those of the authors alone, and do not represent the policies or official positions of the FOEN or the institutions the authors work for. We gratefully acknowledge the comments and feedback of three anonymous reviewers and editorial board member and special issue editor M. Bürgi.

Author contributions FW: conceptualisation, methodology (public survey design), investigation, writing-original draft. CS: methodology (model creation), software, validation, formal analysis, writing-original draft. FK: project administration, funding acquisition, methodology (landscape ecology metrics). $\mathrm{MH}$ : conceptualisation, supervision, funding acquisition.

Funding Open Access funding provided by Lib4RI - Library for the Research Institutes within the ETH Domain: Eawag, Empa, PSI \& WSL.

Open Access This article is licensed under a Creative Commons Attribution 4.0 International License, which permits use, sharing, adaptation, distribution and reproduction in any medium or format, as long as you give appropriate credit to the original author(s) and the source, provide a link to the Creative Commons licence, and indicate if changes were made. The images or other third party material in this article are included in the article's Creative Commons licence, unless indicated otherwise in a credit line to the material. If material is not included in the article's Creative Commons licence and your intended use is not permitted by statutory regulation or exceeds the permitted use, you will need to obtain permission directly from the copyright holder. To view a copy of this licence, visit http://creativecommons.org/licenses/by/4.0/.

\section{References}

Anton CE, Lawrence C (2014) Home is where the heart is: the effect of place of residence on place attachment and community participation. J Environ Psychol 40:451-461

Appleton J (1975) The experience of landscape. Wiley, London

Appleton J (1984) Prospects and refuges re-visited. Landsc J 3(2):91-103

Bieling C (2014) Cultural ecosystem services as revealed through short stories from residents of the Swabian Alb (Germany). Ecosyst Serv 8:207-215 
Bonaiuto M, Aiello A, Perugini M, Bonnes M, Ercolani AP (1999) Multidimensional perception of residential environment quality and neighbourhood attachment in the urban environment. J Environ Psychol 19(4):331-352

Bonaiuto M, Fornara F, Bonnes M (2003) Indexes of perceived residential environment quality and neighbourhood attachment in urban environments: a confirmation study on the City of Rome. Landsc Urban Plan 65(1-2):41-52

Bourassa SC (1988) Toward a theory of landscape aesthetics. Landsc Urban Plan 15(3-4):241-252

Brown G, Raymond C (2007) The relationship between place attachment and landscape values: toward mapping place attachment. Appl Geogr 27(2):89-111

Buijs AE, Elands BHM, Langers F (2009) No wilderness for immigrants: cultural differences in images of nature and landscape preferences. Landsc Urban Plan 91(3):113-123

Butler A (2016) Dynamics of integrating landscape values in landscape character assessment: the hidden dominance of the objective outsider. Landsc Res 41(2):239-252

Cassatella C, Peano A (eds) (2011) Landscape Indicators: assessing and monitoring landscape quality. Springer. https://doi.org/10.1007/978-94-007-0366-7

Chan KMA, Satterfield T, Goldstein J (2012) Rethinking ecosystem services to better address and navigate cultural values. Ecol Econ 74:8-18

Council of Europe (2000) European Landscape Convention. http://www.coe.int/en/web/conventions/full-list/-/ conventions/rms/0900001680080621

Dakin S (2003) There's more to landscape than meets the eye: towards inclusive landscape assessment in resource and environmental management. Can Geogr 47(2):185-200

Daniel TC (2001) Whither scenic beauty? Visual landscape quality assessment in the 21 st century. Landsc Urban Plan 54(1-4):267-281

de San Eugenio Vela J, Nogué J, Govers R (2017) Visual landscape as a key element of place branding. J Place Manag Dev 10(1):23-44

Devine-Wright P (2009) Rethinking NIMBYism: the role of place attachment and place identity in explaining placeprotective action. J Community Appl Soc Psychol 19(6):426-441

Díaz S, Pascual U, Stenseke M, Martín-López B, Watson RT, Molnár Z, Hill R, Chan KMA, Baste IA, Brauman KA, Polasky S, Church A, Lonsdale M, Larigauderie A, Leadley PW, van Oudenhoven APE, van der Plaat F, Schröter M, Lavorel S, Aumeeruddy-Thomas Y, Bukvareva E, Davies K, Demissew S, Erpul G, Failler P, Guerra CA, Hewitt CL, Keune H, Lindley S, Shirayama Y (2018) Assessing nature's contributions to people. Science 359(6373):270-272

Dramstad WE, Tveit MS, Fjellstad WJ, Fry GLA (2006) Relationships between visual landscape preferences and mapbased indicators of landscape structure. Landsc Urban Plan 78(4):465-474

Federal Statistical Office (2011) Arealstatistik Schweiz. Zustand und Entwicklung der Landschaft Schweiz Ausgabe 2011/12. https://www.bfs.admin.ch/bfs/en/home/statistics/ catalogues-databases/publications.assetdetail.347999. html. Accessed 2 July 2011

Federal Statistical Office (2012) Gemeindetypologie und Stadt/ Land-Typologie 2012. https://www.bfs.admin.ch/bfs/de/ home/grundlagen/raumgliederungen.assetdetail.2543323. html. Accessed 2 July 2021

Fokkema M, Greiff S (2017) How performing PCA and CFA on the same data equals trouble. Hogrefe Publishing, Gottingen

Buchecker M, Frick J, Tobias S (2008) Gesellschaftliche Ansprüche an den Lebens- und Erholungsraum. Eine praxisorientierte Synthese der Erkenntnisse aus zwei Forschungsprogrammen. Swiss Federal Institute for Forest, Snow and Landscape Research WSL

Fry G, Tveit MS, Ode A, Velarde MD (2009) The ecology of visual landscapes: exploring the conceptual common ground of visual and ecological landscape indicators. Ecol Indic 9(5):933-947

Gehring K (2006) Landscape needs and notions: preferences, expectations, leisure motivation, and the concept of landscape from a cross-cultural perspective. Swiss Federal Research Institute, WSL, Birmensdorf

Gerbing DW, Anderson JC (1988) An updated paradigm for scale development incorporating unidimensionality and its assessment. J Mark Res 25(2):186-192

Gobster PH (2002) Managing urban parks for a racially and ethnically diverse clientele. Leis Sci 24(2):143-159

Gobster PH, Nassauer JI, Daniel TC, Fry G (2007) The shared landscape: what does aesthetics have to do with ecology? Landsc Ecol 22(7):959-972

Gomez-Limon J, de Lucio Fernández JV (1999) Changes in use and landscape preferences on the agricultural-livestock landscapes of the central Iberian Peninsula (Madrid, Spain). Landsc Urban Plan 44(4):165-175

Gould RK, Klain SC, Ardoin NM, Satterfield T, Woodside U, Hannahs N, Daily GC, Chan KM (2015) A protocol for eliciting nonmaterial values through a cultural ecosystem services frame. Conserv Biol 29(2):575-586

Gustafson EJ (1998) Quantifying landscape spatial pattern: what is the state of the art? Ecosystems 1(2):143-156

Hartig T, Evans GW (1993) Psychological foundations of nature experience. Adv Psychol 96:427-457

Hartig T, Korpela K, Evans GW, Gärling T (1997) A measure of restorative quality in environments. Scand Hous Plan Res 14(4):175-194

Hartig T, Mang M, Evans GW (1991) Restorative effects of natural environment experiences. Environ Behav 23(1):3-26

Hay R (1998) Sense of place in developmental context. J Environ Psychol 18(1):5-29

Hayes AF (2017) Introduction to mediation, moderation, and conditional process analysis: a regression-based approach. Guilford Publications, New York

Hegetschweiler KT, Plum C, Fischer C, Brändli U-B, Ginzler C, Hunziker M (2017) Towards a comprehensive social and natural scientific forest-recreation monitoring instrument-a prototypical approach. Landsc Urban Plan 167:84-97

Hennig EI, Schwick C, Soukup T, Orlitová E, Kienast F, Jaeger JAG (2015) Multi-scale analysis of urban sprawl in Europe: towards a European de-sprawling strategy. Land Use Policy 49:483-498

Hu L, Bentler PM (1999) Cutoff criteria for fit indexes in covariance structure analysis: conventional criteria versus new alternatives. Struct Equ Model Multidiscip J 6(1):1-55 
Hunziker M, Buchecker M, Hartig T (2007) Space and place two aspects of the human-landscape relationship. In: Kienast F, Wildi O, Gosh S (eds) A changing world. Springer, pp 47-62. https://doi.org/10.1007/978-1-40204436-6_5

Hunziker M, Felber P, Gehring K, Buchecker M, Bauer N, Kienast F (2008) Evaluation of landscape change by different social groups. Mt Res Dev 28(2):140-147

Hunziker M, Kienast F (1999) Potential impacts of changing agricultural activities on scenic beauty-a prototypical technique for automated rapid assessment. Landsc Ecol 14(2):161-176

Jackson S, Fuller D, Dunsford H, Mowbray R, Hext S, MacFarlane R, Haggett C (2008) Tranquility mapping: developing a robust methodology for planning support. Report to the campaign to protect rural England. Centre for Environmental and Spatial Analysis, Northumbria University, Bluespace Environments and the University of Newcastle upon on Tyne. https://www.cpre.org.uk/ resources/tranquillity-mapping-developing-a-robustmethodology-for-planning-support/. Accessed 2 July 2021

Jaeger JAG, Bertiller R, Schwick C, Cavens D, Kienast F (2010) Urban permeation of landscapes and sprawl per capita: new measures of urban sprawl. Ecol Indic 10(2):427-441

Jaeger JAG, Bertiller R, Schwick C, Müller K, Steinmeier C, Ewald KC, Ghazoul J (2008) Implementing landscape fragmentation as an indicator in the Swiss Monitoring System of Sustainable Development (MONET). J Environ Manag 88(4):737-751

Jivén G, Larkham PJ (2003) Sense of place, authenticity and character: a commentary. J Urban Des 8(1):67-81

Jorgensen A (2011) Beyond the view: future directions in landscape aesthetics research. Landsc Urban Plan 100(4):353-355

Kaplan R, Kaplan S (1989) The experience of nature: a psychological perspective. Cambridge University Press, Cambridge

Kaplan S (1995) The restorative benefits of nature: toward an integrative framework. J Environ Psychol 15(3):169-182

Kianicka S, Buchecker M, Hunziker M, Müller-Böker U (2006) Locals' and tourists' sense of place: a case study of a Swiss alpine village. Mt Res Dev 26(1):55-63

Kienast F, Degenhardt B, Weilenmann B, Wäger Y, Buchecker M (2012) GIS-assisted mapping of landscape suitability for nearby recreation. Landsc Urban Plan 105(4):385-399

Kienast F, Frick J, Steiger U (2013) Neue Ansätze zur Erfassung der Landschaftsqualität. Zwischenbericht Landschaftsbeobachtung Schweiz (LABES), Umwelt-Wissen Nr. 1325. https://www.bafu.admin.ch/dam/bafu/de/ dokumente/landschaft/uw-umwelt-wissen/neue_ansaetze_ zurerfassungderlandschaftsqualitaet.pdf.download.pdf/ neue_ansaetze_zurerfassungderlandschaftsqualitaet.pdf. Accessed 2 July 2021

Kienast F, Frick J, van Strien MJ, Hunziker M (2015) The Swiss Landscape Monitoring Program - a comprehensive indicator set to measure landscape change. Ecol Model 295:136-150

Kühne O (2017) Landschaftstheorie und Landschaftspraxis: eine Einführung aus sozialkonstruktivistischer Perspektive. Springer, Wiesbaden
Laumann K, Gärling T, Stormark KM (2001) Rating scale measures of restorative components of environments. J Environ Psychol 21(1):31-44

Lewicka M (2011) Place attachment: how far have we come in the last 40 years? J Environ Psychol 31(3):207-230

Lindemann-Matthies P, Briegel R, Schüpbach B, Junge X (2010) Aesthetic preference for a Swiss alpine landscape: the impact of different agricultural land-use with different biodiversity. Landsc Urban Plan 98(2):99-109

Llausàs A, Nogué J (2012) Indicators of landscape fragmentation: the case for combining ecological indices and the perceptive approach. Ecol Indic 15(1):85-91

Lothian A (1999) Landscape and the philosophy of aesthetics: is landscape quality inherent in the landscape or in the eye of the beholder? Landsc Urban Plan 44(4):177-198

Mesch GS, Manor O (1998) Social ties, environmental perception, and local attachment. Environ Behav 30(4):504-519

Meyer EK (2008) Sustaining beauty. The performance of appearance: a manifesto in three parts. J Landsc Archit $3(1): 6-23$

Milcu AI, Hanspach J, Abson D, Fischer J (2013) Cultural ecosystem services: a literature review and prospects for future research. Ecol Soc 18(3): $\operatorname{art44}$

Muthén LK, Muthén BO (1998) Mplus: the comprehensive modeling program for applied researchers: user's guide. Muthén \& Muthén

Nassauer JI (1992) The appearance of ecological systems as a matter of policy. Landsc Ecol 6(4):239-250

Natori Y, Chenoweth R (2008) Differences in rural landscape perceptions and preferences between farmers and naturalists. J Environ Psychol 28(3):250-267

Ode $\AA$, Hagerhall CM, Sang N (2010) Analysing visual landscape complexity: theory and application. Landsc Res 35(1):111-131

Ode $\AA$, Tveit MS, Fry G (2008) Capturing landscape visual character using indicators: touching base with landscape aesthetic theory. Landsc Res 33(1):89-117

Ortiz-Burgos S (2016) Shannon-Weaver diversity index. In: Encyclopedia of earth sciences series. pp 572-573. https:// doi.org/10.1007/978-94-017-8801-4_233

Plieninger T, Kizos T, Bieling C, Le Dû-Blayo L, Budniok M-A, Bürgi M, Crumley CL, Girod G, Howard P, Kolen J (2015) Exploring ecosystem-change and society through a landscape lens: recent progress in European landscape research. Ecol Soc 20(2):5

Preacher KJ, Selig JP (2010) Monte Carlo method for assessing multilevel Mediation: an interactive tool for creating confidence intervals for indirect effects in 1-1-1 multilevel models. [Computer software] http://quantpsy.org/

Scholte SSK, van Teeffelen AJA, Verburg PH (2015) Integrating socio-cultural perspectives into ecosystem service valuation: a review of concepts and methods. Ecol Econ 114:67-78

Siedentop S, Fina S (2012) Who sprawls most? Exploring the patterns of urban growth across 26 European countries. Environ Plan A 44(11):2765-2784

Smith JS (2002) Rural place attachment in Hispano urban centers. Geogr Rev 92(3):432-451 
Stedman RC (2002) Toward a social psychology of place: predicting behavior from place-based cognitions, attitude, and identity. Environ Behav 34(5):561-581

Stedman RC (2003) Is it really just a social construction? The contribution of the physical environment to sense of place. Soc Nat Resour 16(8):671-685

Stephenson J (2008) The cultural values model: an integrated approach to values in landscapes. Landsc Urban Plan 84(2):127-139

Ströbele M, Hunziker M (2017) Are suburbs perceived as rural villages? Landscape-related residential preferences in Switzerland. Landsc Urban Plan 163:67-79

Strumse E (1996) Demographic differences in the visual preferences for agrarian landscapes in western Norway. J Environ Psychol 16(1):17-31

Tobias S, Müller Wahl P (2013) Can place branding support landscape conservation in city-regions? A case study from Switzerland. Land Use Policy 30(1):266-275

Tuan Y-F (1974) Topophilia. In: a study of environmental perception, attitudes and values. Prentice-Hall, Englewood Cliffs

Turner MG (2005) Landscape ecology in North America: past, present, and future. Ecology 86(8):1967-1974

Turner MG, Gardner RH (2001) Landscape ecology in theory and practice, vol 401. Springer, New York

Tveit MS, Ode Å, Fry G (2006) Key concepts in a framework for analysing visual landscape character. Landsc Res 31(3):229-255

Twigger-Ross CL, Uzzell DL (1996) Place and identity processes. J Environ Psychol16(3):205-220. https://doi.org/ 10.1006/jevp.1996.0017
Ulrich RS, Simons RF, Losito BD, Fiorito E, Miles MA, Zelson M (1991) Stress recovery during exposure to natural and urban environments. J Environ Psychol 11(3):201-230

Van den Berg AE, Vlek CAJ, Coeterier JF (1998) Group differences in the aesthetic evaluation of nature development plans: a multilevel approach. J Environ Psychol 18(2):141-157

Walz U, Stein C (2014) Indicators of hemeroby for the monitoring of landscapes in Germany. $\mathrm{J}$ Nat Conserv 22(3):279-289

Wartmann FM, Frick J, Kienast F, Hunziker M (2021a) Factors influencing visual landscape quality perceived by the public. Results from a national survey. Landsc Urban Plan 208:104024

Wartmann FM, Hunziker M, Kienast F (2021b) Landscape Monitoring Switzerland (LABES). Methodological and content-related further development (original: Programm Landschaftsbeobachtung Schweiz (LABES). Methodische und inhaltliche Weiterentwicklung 2018-2020). WSLReport, vol 103. https://www.dora.lib4ri.ch/wsl/islandora/ object/ws1\%3A26109. Accessed 2 July 2021

Wartmann FM, Purves RS (2018) Investigating sense of place as a cultural ecosystem service in different landscapes through the lens of language. Landsc Urban Plan 175:169-183

Publisher's Note Springer Nature remains neutral with regard to jurisdictional claims in published maps and institutional affiliations. 